BIS WORKING PAPERS

No. 64 - March 1999

\title{
PRECARIOUS CREDIT EQUILIBRIA: REFLECTIONS ON THE ASIAN FINANCIAL CRISIS
}

by

Joseph Bisignano

BANK FOR INTERNATIONAL SETTLEMENTS

Monetary and Economic Department

Basle, Switzerland 
BIS Working Papers are written by members of the Monetary and Economic Department of the Bank for International Settlements, and from time to time by other economists, and are published by the Bank. The papers are on subjects of topical interest and are technical in character. The views expressed in them are those of their authors and not necessarily the views of the BIS.

Copies of publications are available from:

Bank for International Settlements

Information, Press \& Library Services

$\mathrm{CH}-4002$ Basle, Switzerland

Fax: +41 61 / 2809100 and +4161/2808100

This publication is available on the BIS website (www.bis.org).

(C) Bank for International Settlements 1999.

All rights reserved. Brief excerpts may be reproduced or translated provided the source is stated. 


\title{
BIS WORKING PAPERS
}

No. 64 - March 1999

\section{PRECARIOUS CREDIT EQUILIBRIA: REFLECTIONS ON THE ASIAN FINANCIAL CRISIS}

\author{
by \\ Joseph Bisignano*
}

\begin{abstract}
This paper examines some of the origins of the recent East Asian financial crisis. It is composed of three parts. The first considers the role of moral hazard in the crisis, specifically the influence of implicit and explicit government guarantees which may have contributed to excess borrowing in East Asia, similar to what occurred in Latin America during the 1980s. We then consider the role played by weaknesses in prudential regulation and supervision of both banks and non-bank financial intermediaries. Insufficient official oversight and poor corporate governance arguably were at the root of the limited financial transparency which prevented the correct assessment of risks by market participants. The combination of these two factors can be argued to have shifted credit markets from an equilibrium with excess borrowing to one with excessive credit rationing, resulting in a severe liquidity crisis. Comparisons are made with the micro-financial vulnerabilities which eventually led to earlier financial crises in Latin America and the Nordic countries.
\end{abstract}

* This is a revised version of the paper prepared for the conference "Asia: An Analysis of Financial Crisis", co-sponsored by the Federal Reserve Bank of Chicago and the International Monetary Fund, Chicago, 8-10 October 1998. The views expressed in this paper are those of the author and in no way represent an official view of the Bank for International Settlements. My thanks go to Bob Aliber, Chris Bennett, Florence Béranger, Henri Bernard, João Cabral dos Santos, Charles Freeland, Gabriele Galati, Stefan Gerlach, Steve Kamin, Jean-Marie Kertudo, Hoil Oh and Henri Pagès for helpful comments and assistance. 



\section{Contents}

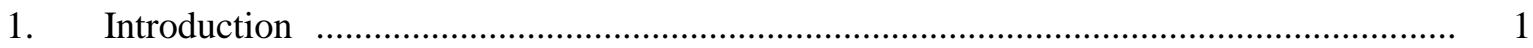

2. Economic development and moral hazard f.............................................................. 2

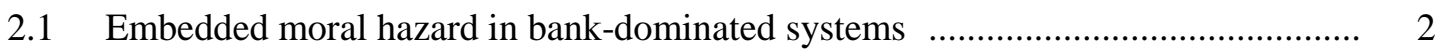

2.2 Moral hazard and excess borrowing ……….................................................. 14

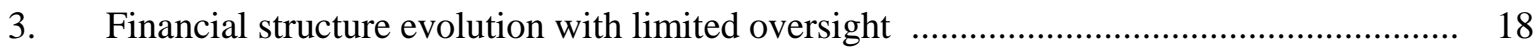

3.1 Excessive momentum and excessive inertia in financial development f................ 18

3.2 Market assessment of banking system health: the weakness of market discipline . 21

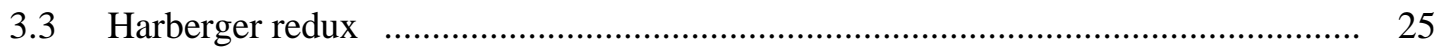

3.4 Short-term capital flows and financial immaturity f......................................... 28

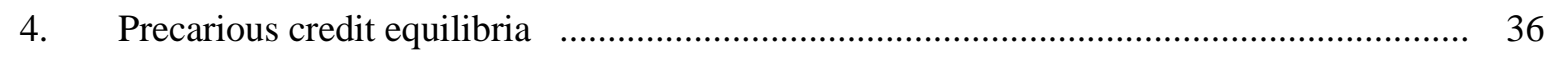

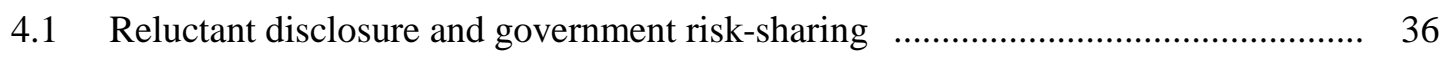

4.2 Unstable risk preferences and capital flow volatility: a stylised characterisation ... 38

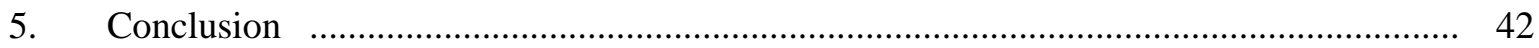

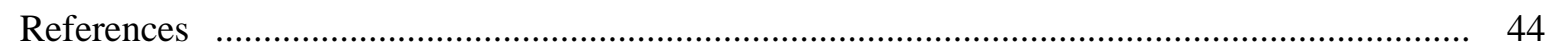





\section{Introduction}

This paper examines some of the origins of the recent East Asian financial crisis. Its focus is on the role of moral hazard and the weakness of prudential regulation and supervision in countries following financial deregulation and capital flow liberalisation. While major differences exist among the Asian countries currently in crisis, there are important similarities between the micro-financial vulnerabilities which eventually led to earlier crises in Latin America, Japan and the Nordic countries. These similarities are illustrated with reference to Korea, Sweden and Chile.

We begin in Section 2 by considering the embedded moral hazard problems in highly concentrated bank-dominated systems. Emphasis is placed on the pervasive role of government in influencing private market credit allocation decisions, in part by providing incentives for the private sector to exploit implicit government guarantees, and on the repeated absence of efficient financial oversight following financial deregulation. Moral hazard is also considered to have contributed to the overborrowing syndrome in East Asia, as it had in Latin America during the 1980s. Given the limited financial transparency in East Asia, it is surprising that, instead of the credit rationing we might have expected in such an environment, we observed large foreign capital inflows, much of it intermediated by banks.

Section 3 considers a few parallels between East Asia and earlier financial crises in Chile and Sweden with regard to the delayed evolution of the prudential regulatory and supervisory function following deregulation. This retarded evolution has been observed in a number of countries since the early 1980s. Attention is also drawn to the difficulty markets may have in evaluating the quality of emerging market banking systems. This section includes a review of Harberger's 1985 study of the Chilean financial crisis of 1981-84 and the role played by the deficiency of financial oversight. Mention is made of opportunities to exploit government guarantees and "inefficient contracts" designed to secure financial stability in the absence of adequate prudential regulation and banking supervision. Because of the deficiencies of corporate governance, transparency and less than adequate attention to supervisory oversight, the financial crisis of East Asia is to a degree a case of self-inflicted wounds.

Section 4 considers the problem of the underproduction of information in the financial systems of emerging market economies and the use of implicit government guarantees to substitute for this deficiency. The credit market in these countries, relying heavily on short-term international capital flows, can be thought of as possessing a "precarious equilibrium", in which foreign flows continue when the implicit guarantee is credible but suddenly revert to extreme credit rationing when the 
implicit guarantee is undermined by the threat of potential widespread financial illiquidity or insolvency. The last section draws a few conclusions.

\section{Economic development and moral hazard}

\subsection{Embedded moral hazard in bank-dominated systems}

As noted earlier by Andersen (1993) and Huh and Kim (1994), a frequently ignored aspect of the rapid growth of many East Asian countries was the general absence of well-developed financial markets. (The obvious exceptions are Hong Kong and Singapore.) This is not uncommon. In the early stages of economic development an efficient, market-based financial system has often been thought to be of second-order importance to economic growth. The banking system typically dominates the intermediation process, often with little-disguised intervention by the government, and usually with widespread implicit stability guarantees. For example, between 1970 and 1990 the net bond financing of corporations in the five East Asian countries for which data exists was less than $10 \% .{ }^{1}$ Several countries in East Asia grew at surprisingly rapid rates of growth without the benefit of well-developed financial markets but with a major participation of government in providing implicit guarantees. ${ }^{2}$

The large role played by governments in developing economies in selecting specific industries for development and in directing and subsidising credit to them is well known. ${ }^{3}$ In the past East Asia and Japan have relied heavily on directed credit programmes to promote specific industries. Selective credit allocation was also used in Indonesia, Malaysia and Thailand. ${ }^{4}$ This pattern of selective investment and credit allocation has frequently delayed and masked the need for the development of the micro-credit analysis structure in the banking industry and appropriate official supervisory oversight. The financial history of Japan should not be forgotten. Successful industrial development programme in Asia often went hand in hand with an underlying weakness in the quality of credit analysis. When financial deregulation took place, it was often without the concurrent development of

World Bank (1993), p. 224.

2 See Goldstein and Turner (1996). In 1994 between 64\% and 90\% of financial intermediation in Indonesia, Malaysia and Thailand was bank intermediation. Before 1983, 80\% of bank deposits in Indonesia were in state-owned banks. McKinnon (1991) emphasises the danger of the combination of moral hazard and financial repression, with real interest rates below a loan-rationing equilibrium.

3 This story for East Asia is described in World Bank (1993). Even loans from foreign banks came under the influence of the government. For example, in 1986 when foreign banks were given access to the Bank of Korea's rediscount facilities for export financing and commercial bills they were required to devote a percentage of their lending to "priority sectors". See Layman (1988).

4 See Stiglitz and Uy (1996) and Folkerts-Landau et al. (1995) on directed credit allocation in East Asia. The latter report that policy loans amounted to almost half of commercial bank lending in Korea in 1990, ten years after banks were privatised. 
an efficient prudential regulation and supervisory structure. In many regards the East Asian experience was typical of developing economies' financial system evolution.

In the mid-1980s Yoshio Suzuki (1986) pointed to the dangers of what he referred to as "socialism in financial markets" in Japan. By this he meant the artificially low interest rate policy used in the promotion of investment/export-led growth in the early stages of postwar Japanese industrial development and, between mid-1970 and early 1980, the high degree of public financial intermediation fostered by continued cheap financing by government intermediaries. ${ }^{5}$ Suzuki warned of three problems which were likely to result from the heavy role of government in financial intermediation. The first was the harm it would cause to the allocation of financial capital. Excessive public intermediation would hamper the growth of private credit institutions, with real investment being based not on the efficiency of capital but on the basis of non-market determined public policy objectives. Secondly, the continued growth of public intermediation would potentially undermine the effectiveness of monetary policy. And thirdly, it threatened to reduce fiscal discipline, as non-market loan criteria would gradually lead to a deterioration in the quality of the loan portfolio of public intermediaries. Developing country governments' intermediation role has also often included partly shielding the private sector from foreign exchange risk by stabilising exchange rates. Although the nature of "public intermediation" was less apparent in many cases, these potential problems have all come to pass in East Asia. The problem for many developing countries has been when and how best to remove the government from its large direct or indirect intermediation role, how to encourage the development of a market-based credit screening and monitoring culture, and how to regulate and supervise a system of private intermediation.

In the early stages of economic development it may be the case that government intervention in investment decision-making and credit extension is desirable and welfare-improving, given serious informational asymmetries, the absence of well-organised financial markets and the size of required infrastructure investments. Because of the frequent absence of well-defined property rights, of an efficient legal system to enforce contract compliance and bankruptcy proceedings, and of transparent accounting and disclosure standards, it is hardly surprising that the banking system typically grows more rapidly than financial markets with tradable debt and equity contracts. ${ }^{6}$ Banks are typically thought to be more efficient than securities markets in resolving agency problems in an environment of severe information asymmetries.

5

Suzuki (1986), pp. 17-25.

6 See Stiglitz (1991) on the role of government in promoting economic development and the dominance of banks over securities. Rojas-Suárez and Weisbrod (1995) emphasise the large role of banks in Latin America. Cho (1986) argues that government intervention in credit markets may be desirable when equity markets are absent and some borrowers, because of information asymmetries, would be unable to obtain finance. However, he admits that forced lending is often inefficient and subject to political corruption. 
In some regards the banking systems in developing countries incorporate several of the aspects of legal and accounting systems by having access to deposit histories and by relying on long-term relationships, the need for loan renewal and collateral requirements to enforce contract compliance and information disclosure. This also frequently involves government stability guarantees and enforcement mechanisms, given the need for banks to fund long-term loans with short-term deposits. One aspect of the moral hazard problem in young financial systems emanates from this close government-corporatebanking sector link, the weakness of "arm's length" financial relationships. In addition, for any economy to function the system requires a reliable payment system. This reliability results from the requirement that banks hold deposits with the central bank and from the central bank's assurance that liquidity will be maintained in times of stress. Hence, there is at the core of the financial system of developing economies an intrinsic insurance-based moral hazard problem: the need to assure an often poorly informed public of the stability of banking intermediaries with predominantly non-marketable information-idiosyncratic loans, where there are few alternatives to bank credit. The pervasiveness of the moral hazard problem related to the banking system can be seen in sovereign credit ratings. Standard \& Poor's, for example, considers banking sector liabilities as contingent liabilities of governments. $^{7}$

Compounding the intrinsic moral hazard problem in developing economies is the weakness of the "bankruptcy threat" for many large firms and banks, potentially weakening financial discipline and encouraging excessive risk-taking. This is a particular problem when political connections reduce manager concern with failure and particularly where firms directly control banks. For example, following privatisation, new "groupos", large conglomerates, emerged in Chile in the early 1970s. Unlike earlier family-centred, conservative groupos, the new ones were aggressive, highly leveraged, and organised around one or more banks. By 1979 they controlled the equity of more than $80 \%$ of all private banks, and almost $70 \%$ of the equity of firms listed on the stock exchange. Even without direct government direction of investment and credit because of their size, the groupos and their banks appeared to rely on implicit government guarantees. As described by Le-Fort (1994), the banks acted as agents of the groupos engaging in risky investment activity despite extremely low capital positions. Confronting difficulty and facing insolvency in 1982, there was the expectation of a "discriminatory bailout". As a result of excessive leverage and large foreign currency borrowing, the two largest groupos went bankrupt in 1983. The government then took over five banks, among them the two largest private banks, owned by important conglomerates. ${ }^{8}$ Direct government control or ownership was not necessary for banks to behave as if government support was assured.

\footnotetext{
7 See Standard \& Poor's (1998a).

8 See Edwards (1995), Chapter 4 for an interesting discussion of the Chilean groupos.
} 
Suzuki's lament over the excessive degree of public intermediation in Japan as late as the early 1980s illustrates how difficult it is, even for advanced industrialised countries, to extricate government from its role in the banking system. Since his writing, events in Japan have illustrated how vulnerable a large, well-capitalised banking system can be to the dangers posed by moral hazard, even after the government has retreated from direct intervention in the financial system. We should also recall that a major difference between Japan's high-growth period without a major banking crisis and the current banking crises in East Asia is that Japan's earlier success took place during a time of limited international capital mobility. The moral hazard potential was there but was arguably kept manageable by the limited access of Japanese firms and banks to foreign short-term capital.

Moral hazard problems in developing economies may also be heightened by their success at achieving rapid real growth and rising standards of living. We saw this in Chile in the 1980s and in Mexico in the 1990s. Early "catch up" economic growth produced by a mobilisation of domestic labour and capital resources, particularly in high saving rate countries, may be misinterpreted as efficiency gains. ${ }^{9}$ Nothing blurs economic vision like success, particularly when its origins are misunderstood, resulting in a postponement of necessary policy adjustment to the new environment. (See Charts 1-3).

The combination of government protection of banks and large enterprises, directed investment allocation, a lack of efficient credit screening and monitoring technology, and a misinterpretation of the sources of rapid economic growth, has been the source of intrinsic moral hazard risks in many developing countries. Park (1998), for example, argues that moral hazard problems played a major part in precipitating the Korean financial crisis. The general opinion was that the Korean government would not allow commercial banks and merchant banking corporations to fail. Unlike commercial banks, which were subject to supervision by the central bank, merchant banks were much more loosely regulated and under the control of the Ministry of Finance. The moral hazard problem may also have influenced the behaviour of foreign institutions lending to Korean banks, many of which may have believed that repayment was implicitly guaranteed by the government, similar to what is thought to have contributed to the banking crisis in Chile in the early $1980 \mathrm{~s}^{10}$

Government protection of domestic banks in East Asian countries can also be observed in banking competition policy and in the responses to previous banking crises. Most of these countries, with the exception of Hong Kong, Singapore and Indonesia, had until recently quite rigid restrictions on both foreign and domestic entry into the banking industry. Most of the expansion in the banking industry

9 See Krugman's (1994) interpretation of Asia's economic miracle as a myth.

10

A similar argument is made by Greenspan (1998), who suggests that creditor banks in the international interbank market may have expected claims on banks in emerging market countries to be protected by a safety net. Hence interbank claims may have been considered to be sovereign lending. 
Chart 1

Real Gross Domestic Product and Consumer Prices

$\%$ change over one year
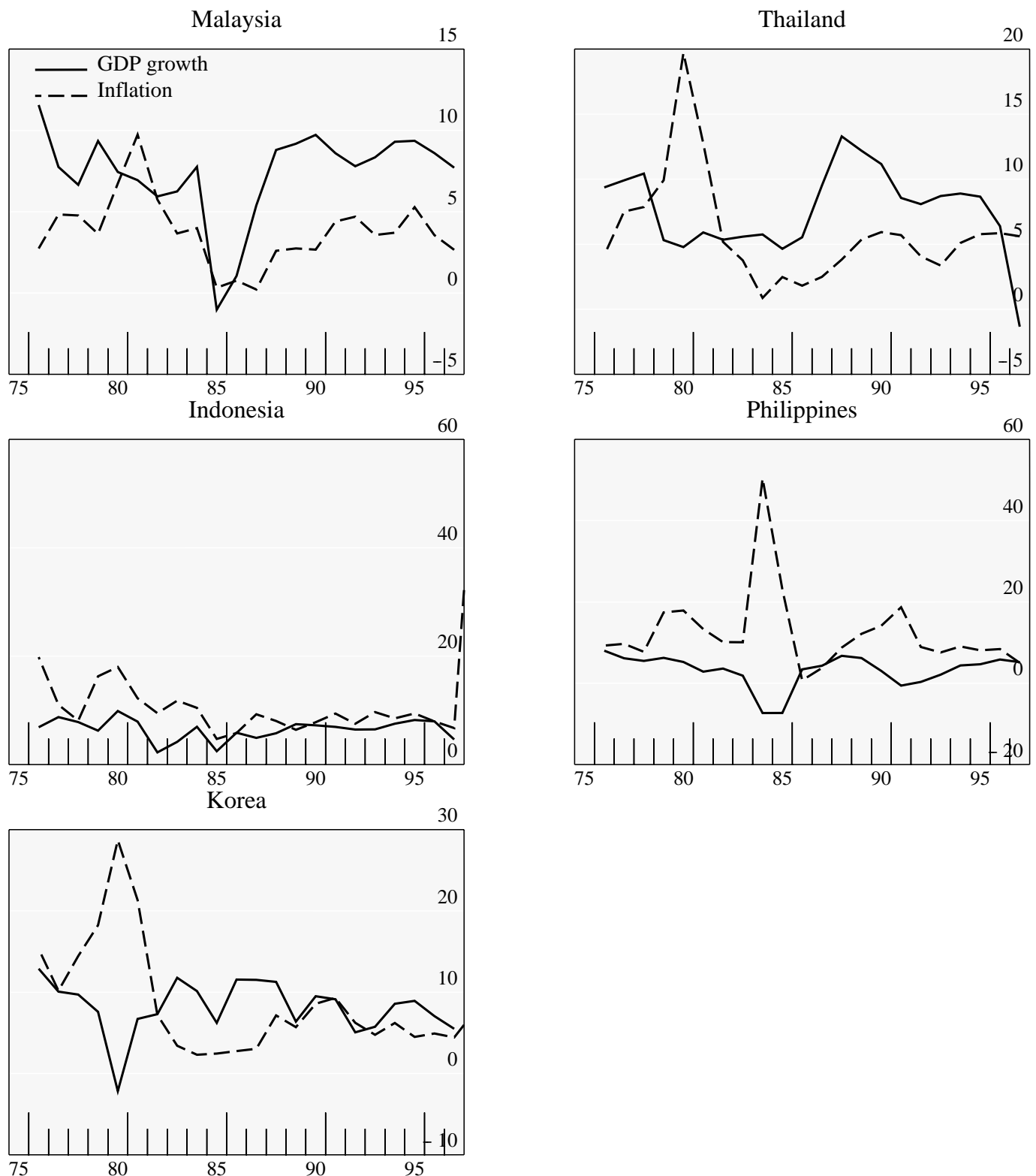
Chart 2

External and Government accounts

$\%$ of GDP
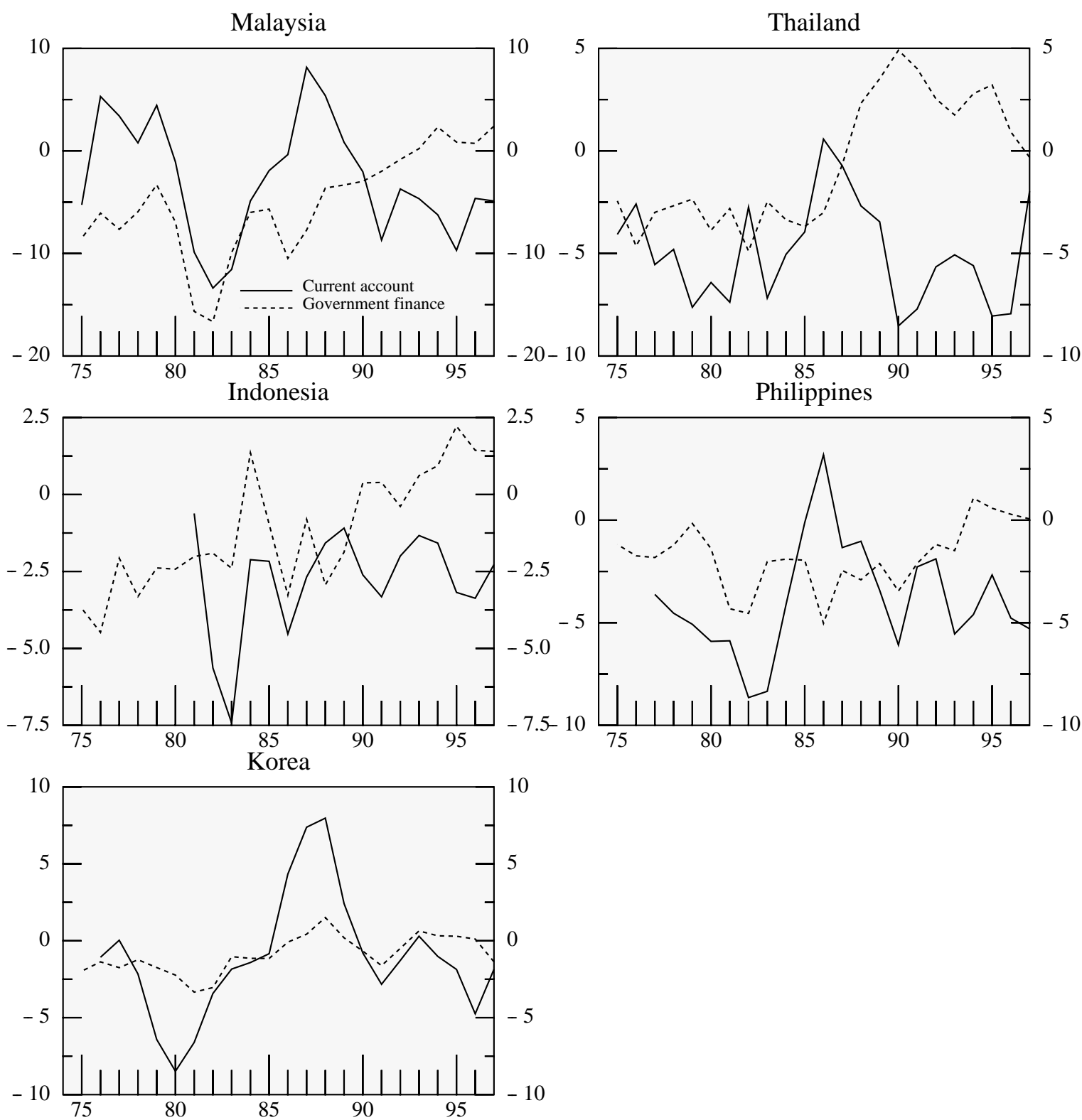
Chart 3

Investment, saving and domestic credit

$\%$ of GDP
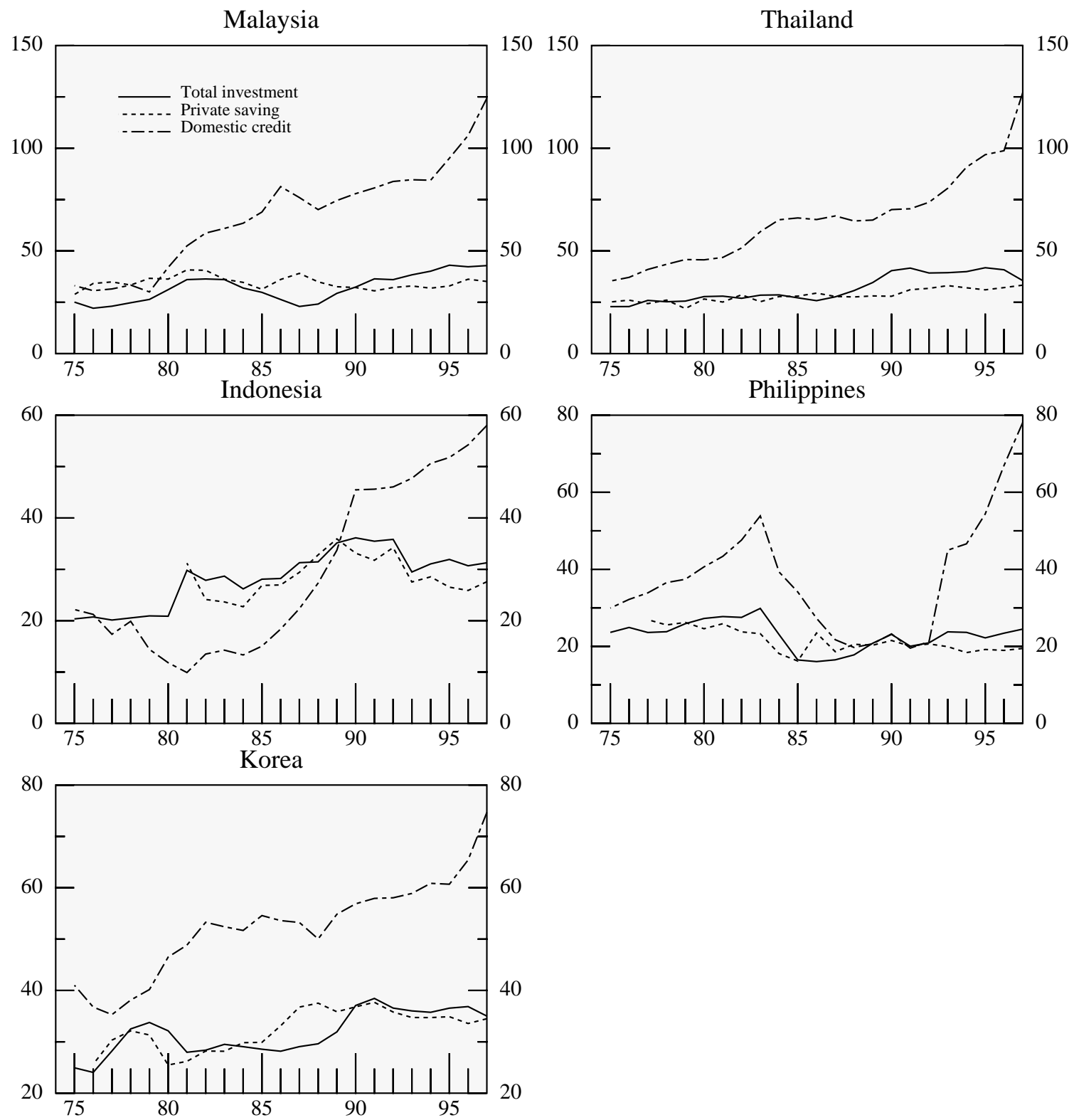
Table 1

Growth of real bank credit to the private sector ${ }^{1}$

\begin{tabular}{|c|c|c|c|c|c|c|}
\hline & \multirow[t]{2}{*}{ 1981-89 } & \multirow[t]{2}{*}{$1990-97$} & \multirow[t]{2}{*}{1996} & \multirow[t]{2}{*}{1997} & \multicolumn{2}{|c|}{$\begin{array}{l}\text { Memorandum item: Bank } \\
\text { credit }^{2} \text { to the private sector } \\
\text { as a percentage of GDP }\end{array}$} \\
\hline & & & & & 1980 & 1997 \\
\hline India & 7.8 & 4.6 & 7.6 & 5.5 & 20.2 & 24.5 \\
\hline China $^{3}$ & 12.1 & 13.0 & 16.4 & 18.8 & 47.5 & 96.5 \\
\hline Hong Kong & 13.0 & 7.7 & 6.9 & 16.5 & 71.2 & 156.1 \\
\hline Taiwan & 15.0 & 12.6 & 4.4 & 5.0 & 49.2 & 138.4 \\
\hline Indonesia & 22.4 & 17.9 & 11.5 & 19.2 & 8.1 & 54.1 \\
\hline Korea & 13.3 & 11.6 & 11.9 & 15.1 & 36.3 & 65.6 \\
\hline Malaysia & 11.2 & 16.1 & 24.5 & 23.3 & 33.1 & 96.6 \\
\hline Philippines & -4.6 & 18.0 & 39.9 & 27.7 & 30.6 & 52.1 \\
\hline Singapore & 10.0 & 12.0 & 15.1 & 11.2 & 62.9 & 96.8 \\
\hline Thailand & 14.8 & 17.7 & 11.6 & 8.6 & 27.6 & 104.5 \\
\hline Argentina & -2.3 & 4.2 & 2.8 & 12.2 & 16.6 & 18.0 \\
\hline Brazil & 6.7 & 2.3 & -2.5 & -2.3 & 17.5 & 24.2 \\
\hline Chile & 7.8 & 10.6 & 18.2 & 9.3 & 26.5 & 52.9 \\
\hline Colombia & 6.6 & 8.9 & 6.2 & 7.8 & 10.8 & 20.0 \\
\hline Mexico & -2.0 & 5.2 & -38.7 & -26.7 & 12.8 & 12.2 \\
\hline Peru & -12.7 & 26.6 & 32.5 & 26.3 & 5.8 & 19.0 \\
\hline Venezuela & -2.6 & -9.1 & -16.3 & 51.0 & 24.9 & 8.5 \\
\hline \multicolumn{7}{|l|}{ Memorandum } \\
\hline United States & 4.8 & 0.4 & 3.7 & 5.1 & 62.1 & 65.2 \\
\hline Japan & 7.7 & 1.4 & 1.5 & -1.3 & 80.8 & 111.6 \\
\hline G-10 Europe ${ }^{4}$ & 5.7 & 3.5 & 2.7 & 3.5 & 60.2 & 88.7 \\
\hline
\end{tabular}

came through the granting of licences for branches of existing banks. The World Bank reports that entry restrictions were preferred to high capital standards "to encourage prudent behaviour" because this provided governments with "a more discretionary tool to influence the behaviour of the banks". 11 We observe the umbrella of implicit guarantees of the banking systems in East Asia in government treatment of weakened institutions. Although only Korea and Thailand had explicit deposit insurance programmes, all other countries in East Asia have had implicitly insured deposits. ${ }^{12}$ Up to 1993 only Hong Kong and Thailand closed the doors of insolvent intermediaries. What is curious in retrospect is

\footnotetext{
11 World Bank (1993), p. 215.

12 Deposit insurance was introduced in Korea only in 1996.
} 
the statement by the World Bank that "because of tougher prudential supervision and better economic growth, the costs of bank rescues in East Asia have been lower than in many other economies". ${ }^{13}$

\section{Chart 4}

\section{Rate of bank credit expansion in real terms ${ }^{1}$}

In percentages

\section{Mexico}

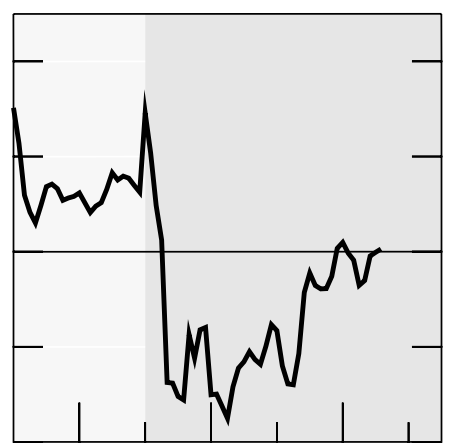

\section{Malaysia}

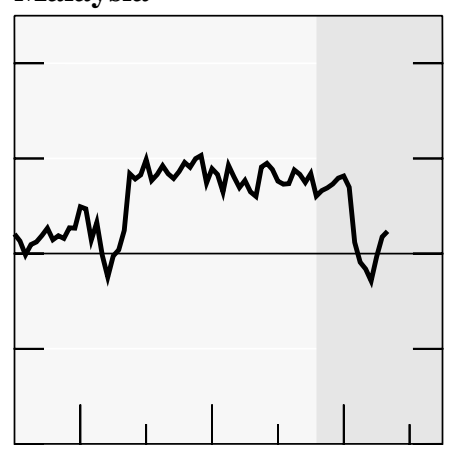

\section{Hong Kong}

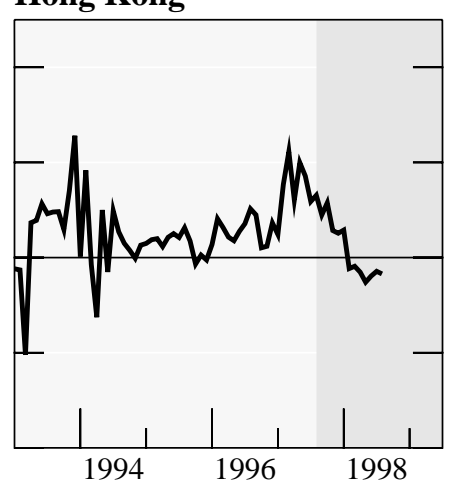

Indonesia $^{2}$

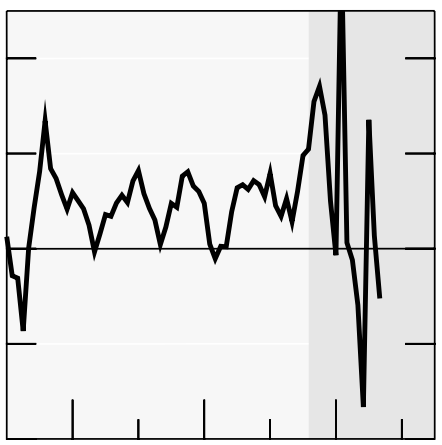

Philippines

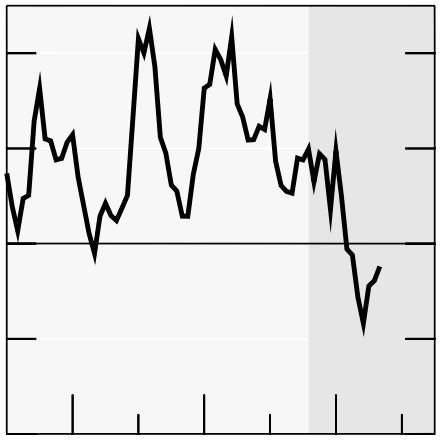

Singapore

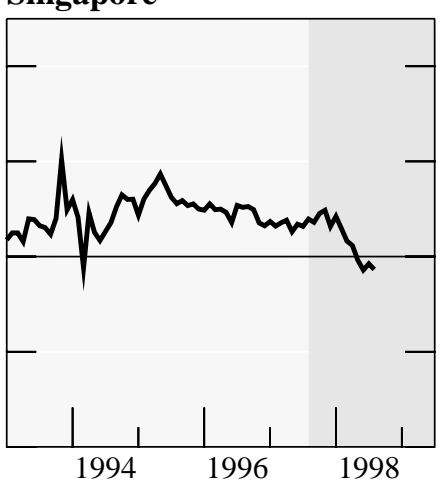

Korea

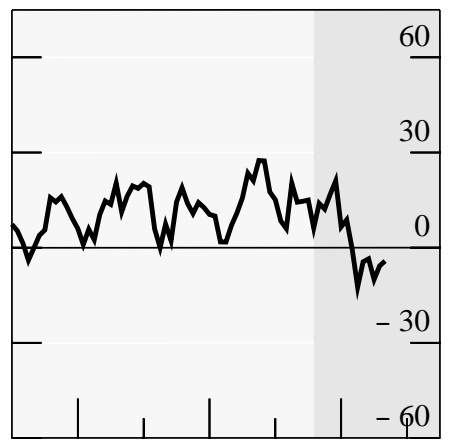

Thailand

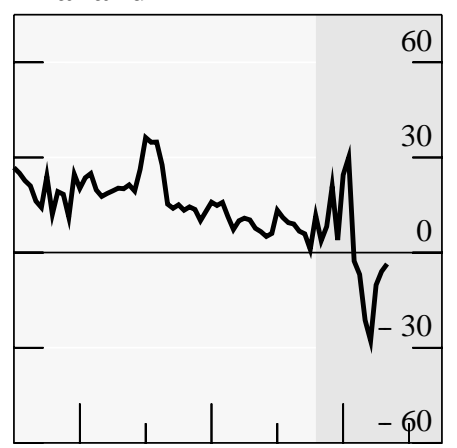

Taiwan

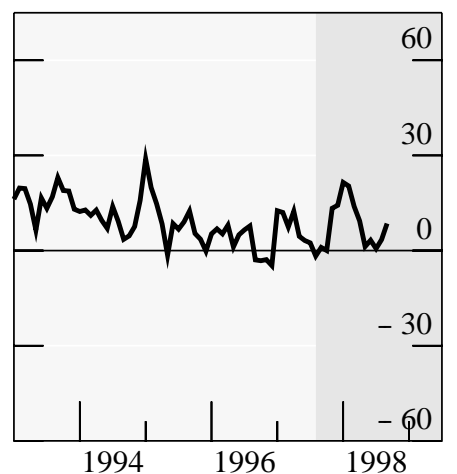

Note: The shaded areas indicate the period from the outbreak of the crisis, i.e. from December 1994 for Mexico and from July 1997 for Asia.

${ }^{1}$ Four-month annualised percentage change in bank credit to the private sector deflated by the same percentage change in consumer prices. ${ }^{2}$ For 1998, excluding credit in foreign currency.

Sources: IMF and national data.

13 World Bank (1993), p. 215. 
An indication of the pervasiveness of implicit government guarantees of financial intermediaries in many developing countries is the repeated occurrence of only limited improvement in the supervision of financial intermediaries immediately before or after rapid financial deregulation and the privatisation of state enterprises. Deregulation has frequently been accompanied by the rapid growth of little regulated non-bank financial intermediaries, a major credit expansion and large rises in asset prices, followed by severe credit problems, if not crises. ${ }^{14}$ This pattern was observed in Argentina after the rapid deregulation in 1978 and in Chile beginning in 1974 with the reduction in reserve requirements, the entry of the "financieras", new non-bank financial intermediaries, and later the privatisation of nationalised banks. ${ }^{15}$ In Venezuela, prior to 1989 the banking system consisted of a variety of specialised banks which were members of financial groups, largely beyond the supervisory reach of the Superintendency of Banks. As Garcia-Herrero (1997) reports, between 1989 and end1993, when the Venezuelan banking crisis exploded, the supervisory and regulatory structure was left basically unchanged due to delays in adopting the financial reform programme that was to complement the country's macroeconomic programme.

The financial deepening in Korea took place in the less regulated/supervised non-bank financial intermediary sector, which was also covered by widespread implicit government guarantees. The Korean Deposit Insurance Corporation was established only in June 1996 because, in the view of its president, "Korean financial institutions were virtually immune to failure because the government implicitly guaranteed the solvency and liquidity of financial institutions through the central bank's function as the lender of last resort". ${ }^{16}$

Following the 1991 financial reform, in which most short-term lending rates of banks and non-bank intermediaries were deregulated, as well as those on a variety of money and capital market investments, competition intensified. It increased further in 1993 when lending rates were further liberalised. This was followed by deposit rate liberalisation in 1994. Although initially slow and cautious during the 1980s, financial deregulation in Korea was later followed by the rapid growth of three types of non-bank financial intermediaries: investment and finance companies, mutual savings intermediaries and merchant banking corporations. ${ }^{17}$ These institutions were provided with the ability to pay higher interest rates than banks, as well as greater management autonomy. This was done in

14 Lightly regulated finance companies played a big role in undermining financial stability in Thailand, as earlier in Sweden. Such institutions were often owned or funded by banks, as they were in Sweden, engaging in activities banks were restrained from conducting.

15 See Edwards and Edwards (1987), Edwards (1995), Rojas-Suárez and Weisbrod (1995), Sundararajan and Baliño (1991) and Garcia-Herrero (1997). Note that financial liberalisation in Korea did not immediately lead to a major expansion in credit growth as seen in most countries following deregulation. On this point see W.-A. Park (1996).

16 J.-S. Park (1998).

17 W.-A. Park (1996) provides an overview of the financial liberalisation experience in Korea. 
order to attract funds from the unregulated money market. They grew quickly: non-commercial bank intermediaries" share of total "deposits" rose from 37\% at end-1980 to 68\% by June 1995.

Table 2

Korea: Foreign funds raised and employed by merchant banks

Units: millions of US dollars, percent

\begin{tabular}{|l|l|r|r|r|r|r|r|}
\hline \multicolumn{2}{|l|}{} & \multicolumn{1}{|c|}{1992} & \multicolumn{1}{c|}{1993} & \multicolumn{1}{c|}{1994} & 1995 & 1996 & \multicolumn{1}{c|}{1997} \\
\hline \multirow{3}{*}{$\begin{array}{l}\text { Funds } \\
\text { raised }\end{array}$} & long-term & 1,276 & 1,953 & 2,182 & 4,568 & 5,996 & $5,428(28.4)$ \\
\cline { 2 - 8 } & short-term(A) & 3,258 & 3,573 & 5,083 & 7,091 & 12,627 & $13,684(71.6)$ \\
\cline { 2 - 8 } & total & 4,534 & 5,526 & 7,265 & 11,659 & 18,623 & $19,113(100)$ \\
\hline \multirow{2}{*}{$\begin{array}{l}\text { Funds } \\
\text { employed }\end{array}$} & long-term & 4,418 & 5,382 & 7,114 & 11,442 & 17,823 & $17,106(89.5)$ \\
\cline { 2 - 8 } & short-term(B) & 116 & 144 & 151 & 217 & 800 & $2,007(10.5)$ \\
\cline { 2 - 8 } & total & 4,534 & 5,526 & 7,265 & 11,659 & 18,623 & $19,119(100)$ \\
\hline Liquidity ratio(B/A) & 3.6 & 4.0 & 3.0 & 3.1 & 6.3 & 14.7 \\
\hline Liquidity ratio of commercial banks & 83.2 & 87.9 & 80.6 & 77.5 & 77.7 & 93.4 \\
\hline
\end{tabular}

Note: Figures in parentheses are percentage shares in total funds raised or total funds employed.

Source: Financial Crisis in Korea. Research Department, The Bank of Korea (July 1998).

Among the more aggressive Korean institutions attempting to profit from the new liberal financial environment were merchant banks, which were permitted to engage in foreign exchange business after 1994. They quickly developed a serious maturity mismatch. By 1997 over $70 \%$ of their funds raised were short-term, while almost $90 \%$ of their placements were long-term, many in high-risk investments in South-East Asia, Russia and Latin America. In addition, according to official sources, merchant banks were improperly supervised, with the quality of their assets poorly examined.

Another Asian example of deficiencies in regulation and supervision following financial deregulation is the Indonesian experience during the late 1980s. Indonesia introduced a number of liberalising measures during the 1980s which were further enhanced with the PAKTO programme in 1988. The result was the rapid entry and growth of private banks. Between 1978 and 1995 the number of banks almost doubled and the number of bank branches more than tripled. According to the Asian Development Bank, the regulatory and legal structure was simply unable to manage a much more diversified and competitive banking system. ${ }^{18}$ For one thing, there was a deficiency of banking

18 See Dickie (1997) 
supervisors and auditors. In consequence, there was a serious decline in the standards of credit evaluation, supervision and portfolio quality. Large bank losses followed.

Chart 5

Korea: stock and land prices

(Annual percentage changes)

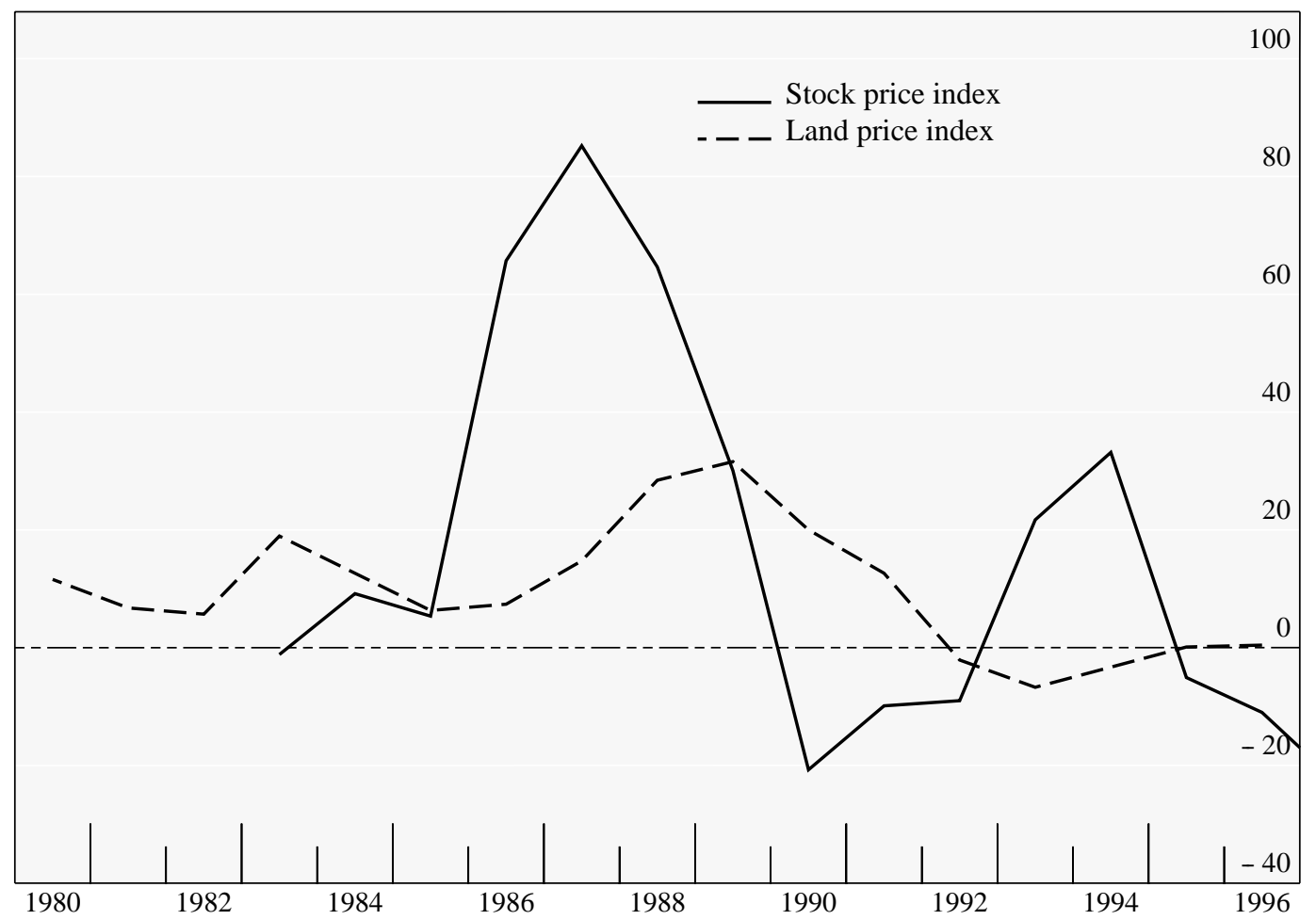

Source: Bank of Korea

Further expanding the moral hazard umbrella has been the treatment of weak or failing banks in developing countries. With few exceptions the government was there to catch those that fell. Even where the banking system was largely in the private sector, banks were bailed out. At the onset of the Venezuelan banking crisis in late 1993 approximately $90 \%$ of deposits were in private banks. Given the oligopolistic structure of the industry, with the six largest banks holding $52 \%$ of all banking assets, 
and with these held by just a few individuals, the ability of the supervisory authorities to effect anything other than a complete coverage of all depositors was seriously limited. ${ }^{19}$

In East Asia we have observed similar cases of highly concentrated banking systems, inadequate prudential regulation and supervision, implicit government guarantees and imprudent lending resulting in financial crises and the need for large government assistance. Major government support was provided to financial institutions in Malaysia in 1985-88, in Thailand 1983-87 and in the Philippines between 1981 and 1987, to cite just a few examples.

A number of studies conducted by the International Monetary Fund and the World Bank on the origins of banking crises in developing economies since the early 1980s point to the weakness of prudential regulation and supervision. Where attempts were made to strengthen them they were often only made after a crisis and insufficient to prevent another. While in several cases the trigger was a major external shock, it is remarkable how many crises had contributing factors which could have been prevented by effective prudential regulation and supervision. And behind these factors has been a major source of vulnerability of banking systems in both developed and developing countries, namely the simple lack of independence of the financial supervisory authorities.

\subsection{Moral hazard and excess borrowing}

In recent years a number of authors have argued that emerging market economies are often subject to an "overborrowing syndrome" resulting from moral hazard. ${ }^{20}$ The source of the moral hazard is sometimes attributed, as in McKinnon (1991) and McKinnon and Pill (1996 and 1998), to explicit or more commonly implicit deposit insurance. Illustrations have been given of a number of Latin American episodes of rapid and excessive debt and investment build-up followed by financial crisis and collapse.

A difficulty with many of these arguments is that we have no good discriminating mechanism to select among alternative candidates giving rise to the moral hazard. It may be best to simply conclude, as The Bank of Korea has in the review of its financial crisis, that, "... moral hazard was prevalent among all economic actors including enterprises, financial institutions, workers and depositors". ${ }^{21}$ The assumed prevalence of moral hazard in Korea suggests that the true origins of the financial crisis are much deeper and more widespread than simply deposit insurance. It suggests that the roots of the crises in Asian emerging market countries are similar to those currently facing Japan, namely the

\footnotetext{
19 Garcia-Herrero (1997).

20 The notion of "overborrowing" used here is clearly not rigorous. To be so would require a well-specified model to determine a sustainable debt level for private firms and intermediaries.

21 The Bank of Korea (1998), p. 11.
} 
incentive and information structure of the financial system and the system of corporate governance which encourages highly leveraged enterprises and intermediaries.

Regarding the role of information, we know from the theory of agency that an optimal "first-best" sharing of investment risk cannot be achieved when the agent and the principal are risk-averse and there is limited information. ${ }^{22}$ Second-best solutions can be found to reduce the costs of agency by improving the public disclosure of accounting information. In this light, consider the Bank of Korea's recent explanation of the causes of its financial crisis:

"If one thing had to be pointed out as the primary cause of the financial crisis, it would be the country's loss of confidence in the eyes of institutional investors, a loss primarily due to inadequate transparency. First, there was a loss of accounting transparency. ... It was difficult to grasp the actual status of firms. ... Their profits were often overstated by internal transactions among them. ... In the case of financial institutions, the scale of bad loans was underestimated. Figures for banks' nonperforming loans were announced by supervisory authorities, but they were underestimated by excluding substandard loans. ... Thus, banks' apparent soundness was based on unreliable figures.... The lack of transparency, one of the weakest points of the Korean economy, was nothing new, and had grown up as a tradition during the thirty odd years of rapid growth. ... However, international investors did not have a full recognition of its seriousness". ${ }^{23}$

Here we have a puzzle. If we lean on our traditional models of lending in a world of severe information asymmetries between borrowers and lenders, we do not arrive at what has been observed in Asia, the so-called overborrowing syndrome. The now classic Stiglitz-Weiss (1981) model, where banks face potential borrowers with projects of the same expected return but different riskiness, but are unable to differentiate between different risk classes of borrowers, leads not to excess borrowing but to less than "optimal" lending. ${ }^{24}$ The "equilibrium" in such a loan market should be one of credit rationing. Recognising that raising the loan interest rate or increasing collateral requirements is likely to attract riskier borrowers and chase away good ones, as a protective device the bank resorts to restricting credit availability. Furthermore, we would expect credit rationing in a market in which loan repayment is not enforceable and where borrowers may choose not to repay when the cost of default is

22 See Barnea, Haugen and Senbet (1985).

23 The Bank of Korea (1998), pp. 9-10. Similarly, Thailand has admitted having difficulty in negotiating with foreign investors in seeking to recapitalise its banking system because of information disclosure problems. See Bank of Thailand (1998), pp. 65-6. Poor accounting standards were known to exist in many of the APEC developing countries. For example, an IMF study in 1995 found an absence of standards to ensure consistency in financial accounting by banks in Indonesia and a limited ability of auditors to inspect company accounting documents in the Philippines. See FolkertsLandau et al. (1995).

24 Of course, banks in the Stiglitz-Weiss model are not insured by implicit government guarantees. 
less than the required repayment. ${ }^{25}$ Credit rationing could be desirable in a world of limited transparency even for "good borrowers", since with fewer defaults average lending rates would not need to incorporate a large default risk premium. Moreover, the banking system would probably be more stable, as aggregate bank profitability would be expected to improve.

We are then faced with the obvious question: if the quality of information on potential borrowers was so questionable in many of the Asian crisis countries, why was so much lent? Indeed, why in recent years were foreign lenders so willing to provide billions of dollars of credits to Asian borrowers in a world with severe information problems?

Three arguments might be put forward to explain the overborrowing syndrome, which could just as well be called the overlending syndrome: competition, long-term relationship banking and moral hazard. The first hypothesis, related to the supply of credit, would rely on competitive forces in the financial industry, particularly like those in Korea, which saw the aggressive entry of lightly regulated non-commercial bank intermediaries. New entrants into the banking industry may not find it profitable to attract competitors' borrowers by offering lower interest rates, since lower rates will be matched for good borrowers but not for bad. Instead, both new and old intermediaries may compete by oversupplying credit at the prevailing interest rate. ${ }^{26}$ We saw such behaviour in the earlier Nordic banking crisis. This problem may have been magnified by the increased liberalisation in East Asian financial markets occurring during a period of low interest rates in the major industrial countries, abundant international credit availability and the aggressive search for returns by banks and institutional investors in the major financial centres.

Alternatively, an oversupply of credit may result from the dominance of relationship banking over securities markets. This may be the case where major lending decisions are partly centralised, as they have been in some developing countries, or "encouraged" by political pressure. Where long-term relationship lending predominates and lender sunk costs have been paid in developing the relationship, the threat of a cut-off of lending may be an idle one, causing the borrower to undertake riskier projects than it would if the threat were credible. On the other hand, where lending is non-centralised, as in securities markets, the borrower may be held on a "shorter credit leash", the cut-off threat more credible and overborrowing less likely. ${ }^{27}$

25

Such a model is considered in Jaffee and Russell (1976). The bank may ration credit in order to ensure that the cost of default remains greater than the repayment. Implicit government guarantees would tend to reduce the cost of default. Allen (1983) extends the Jaffee-Russell result by considering an endogenous cost of default, this being exclusion from the loan market. If this threat is credible credit will be rationed. An ample supply of alternative credit sources and implicit government credit guarantees would reduce the potential cost of default, and reduce the likelihood of credit rationing.

26 See Stiglitz and Weiss (1981), p. 409.

27 This point is rigorously made by Dewatripont and Maskin (1995). Miller (1998) offers the advice that South-East Asia and China should follow the US example and shrink their banking industry, calling banking a "disaster-prone 19th century technology". Instead, they should rely on market alternatives to bank loans. 
Chart 6

\section{Korea: capital ratio trends}

Capital/total liabilities - manufacturing sector

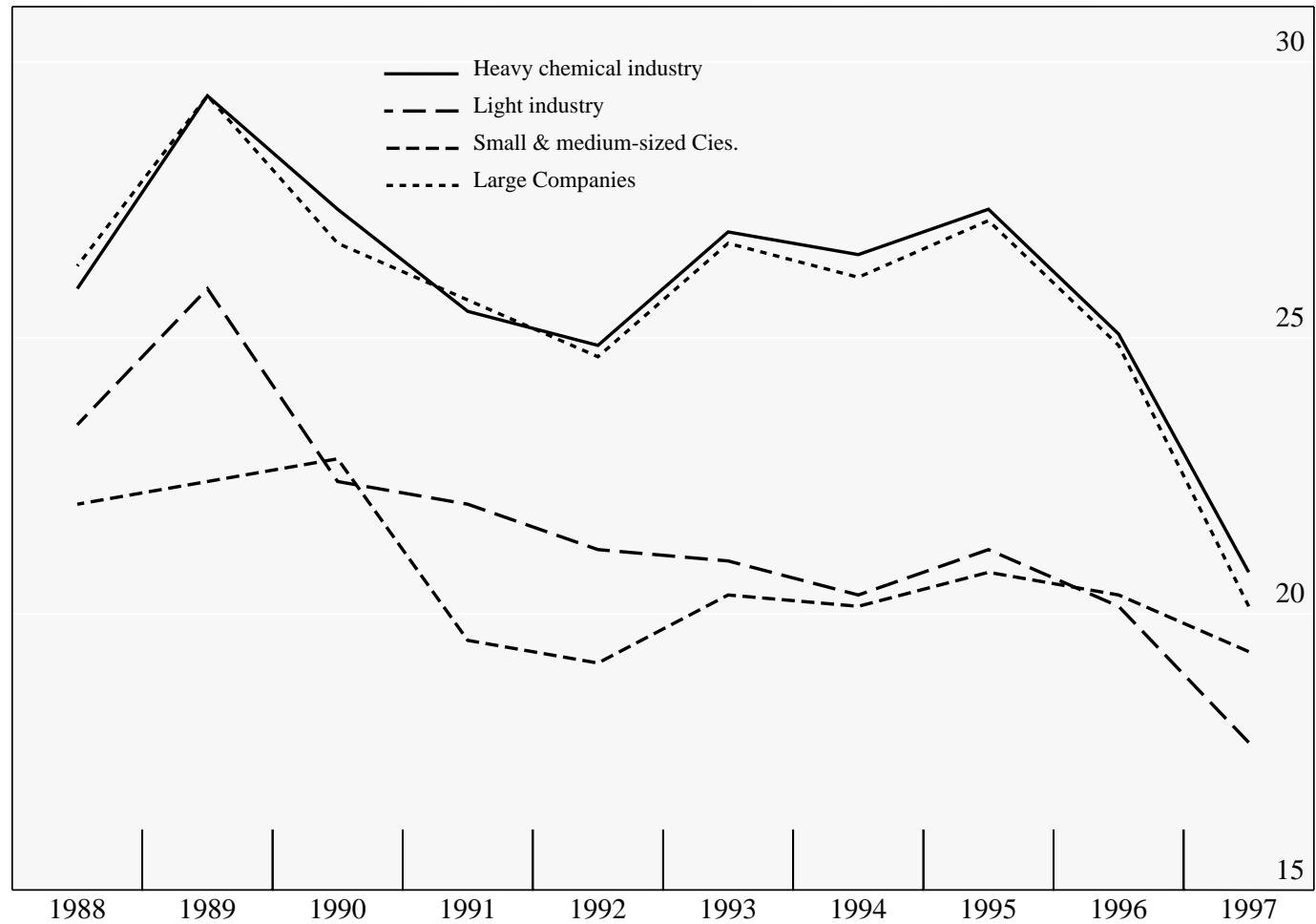

Source: Bank of Korea, Financial Statement Analysis 
A third possible explanation for the overborrowing/lending syndrome is moral hazard, as argued earlier. The recent frank discussion by The Bank of Korea, noting that Korean financial institutions "depended on government control and protection over a long period of time", gives us some insight into the depth of the problem: "The business style of Korean banks was usually to make loans to large enterprises and to those who were able to offer collateral such as real estate, without thoroughly screening their investment plans". ${ }^{28}$

The pattern of passing the ultimate credit risk "upstream" to the government is reminiscent of the "danger of financial socialism" which Suzuki (1986) noted in Japan, which would ultimately harm the efficient allocation of resources. Like Japan, several East Asian countries relied on mutual risk-sharing arrangements with related firms and intermediaries and implicitly with the government to crank up corporate leverage much higher than observed in most western economies. (see Chart 6 on leverage in Korea).

Hanging the story of excess borrowing in East Asia on deposit insurance thus seems a narrow argument. Aggressive competition with recent entrants into the newly deregulated financial system, the pervasiveness of relationship lending in a culture of mutual risk-sharing and widespread moral hazard are all likely to have contributed to the "overborrowing syndrome" in several East Asian countries.

\section{Financial structure evolution with limited oversight}

\subsection{Excessive momentum and excessive inertia in financial development}

Evident in East Asia and a recurring problem in many developing countries has been the delayed evolution of the prudential regulatory and supervisory function, particularly after the relaxation of constraints on intermediation and the privatisation of state-owned enterprises. What appears to occur is "excessive momentum" on the part of the private sector to exploit new profit opportunities and holes in the regulatory/supervisory structure and "excessive inertia" on the government's side in putting in place a rigorous financial oversight function. Further inertia is seen in the frequent reluctance of regulators to force financial intermediaries to make adequate provisioning and to write off bad loans resulting from rapid credit growth soon after deregulation. The consequence has often been a combination of financial opportunism and moral hazard leading to excessive credit growth, asset price bubbles and financial collapse. The crisis is frequently more severe when domestic firms and banks have access to foreign capital.

28 The Bank of Korea (1998), p. 12. 
The recent experience of several East Asian countries is reminiscent of the growth expectations and financial excesses seen in Chile during the late 1970s and early 1980s. ${ }^{29}$ In the Chilean experience, considered later, we saw the contribution to excessive borrowing of each of the factors mentioned earlier: relationship lending, where in the Chilean case large conglomerates owned banks, aggressive competition, often from non-bank intermediaries, and embedded moral hazard. As argued by Edwards and Edwards (1987), because of the degree of moral hazard in the banking system, depositors had little incentive to try to discriminate between sound and unsound banks. Similarly, Park (1998) has argued that implicit guarantees eliminated the incentive for foreign lenders to analyse carefully the credit quality of Korean banks.

The excessive growth optimism in Chile during the late 1970s and the lack of efficient bank loan screening and monitoring are not significantly different from the conditions which preceded the recent East Asian financial crises. The recent problems of Korean banks, for example, were to some extent anticipated in the work of Huh and Kim (1994). They attempted to determine whether Japan or Korea, both with heavily bank-centred financial systems, had the more "efficient" banking system by examining the bad loan rate for each country. ${ }^{30}$ They argued that the more privately owned Japanese banking system, with substantial business loan monitoring by the main bank, was more efficient than the Korean model, where the government earlier had a major ownership in the banking system, and where "bankers were treated as civil servants" and "performance was evaluated on their compliance to the government guidelines rather than their efficient management of assets and liabilities" (p. 25). They suggest that Korean banks were earlier required by the government to understate non-performing loans and to keep them on their books rather than taking write-offs or making loan loss provisions.

The examples of Chile and Korea facing endemic moral hazard problems and liberalisation without sufficient supervision should not be taken to suggest that it is primarily developing/emerging market countries which have faced such problems. The inertia of governments in adopting adequate regulatory and supervisory systems before financial deregulation has occurred with surprising frequency in a number of industrial economies. While different in many regards, the deregulatory process, rapid credit growth and the resulting banking crisis in Sweden during 1991-94 show a number of similarities to the crisis in East Asia.

For many years the Swedish banking system had been tightly regulated with the specific objective of avoiding banking failures. Between 1945 and 1983 no new private bank was created. While some inefficiencies were apparent, the confidence in the banking system was sufficient for a prominent

29

See Edwards and Edwards (1987), Chapter 3.

30

Weinstein and Yafeh (1998) argue that close bank-firm relationships in bank-centred financial systems benefit banks more than firms. In the case of Japan they show that main bank clients did not grow faster, nor were they more profitable, than firms without main bank ties. 
Swedish economist to suggest in 1986 that "the idea of a run on a bank or a bank collapse is out of the question". 31 For many years there was an extensive system of formal and informal contracts between banks and industrial firms, with commercial banks replacing "market relations to their industrial clients with coordination, monitoring and hierarchical control". ${ }^{32}$ Long-term relationships between banks and large firms were traditional in Sweden, the most notable being that between the Wallenberg Group and Stockholms Enskilda Bank. Often relationships were cemented by a firm having only one bank. $^{33}$

As Ingves (1997) has stated, "the financial institutions were clearly not prepared to handle financial liberalisation". An easy bank life of credit rationing in Sweden gave way to intense competition, with banks struggling for market share and survival. Not unlike the state of financial oversight in some emerging market countries, the Financial Supervisory Authority (FSA), according to Ingves, "lacked the competence and the instruments to make assessments of the financial risks and other important developments pertaining to the financial institutions. ... Most importantly, guidelines for internal controls and the proper management of various risks were inadequate".

Similar to some Asian countries, the over-regulation of the Swedish banking industry until the 1980s spurred the development of a largely unregulated financial sector. Constraints on the intermediated sector encouraged the growth of a non-intermediated (direct finance) sector. While the banking system was suffering under the burden of heavy liquidity ratios, requiring banks to hold large quantities of public sector bonds, the non-banking financial sector grew rapidly. Finance houses sidestepped lending regulations, overreaching their original purview of leasing and factoring with heavy lending to small and medium-sized enterprises. The less-regulated finance company sector engaged in highly leveraged mortgage lending, helping to fuel a boom in real estate prices. When the collateralised asset bubble burst the finance companies fell, taking with them some of their banks. Between early 1988 and October $199050 \%$ of Swedish finance companies went out of business. This is similar to the behaviour of non-bank intermediaries in Thailand and Korea.

True, the extreme corporate leverage encouraged by implicit government guarantees in Korea was absent in the Swedish banking crisis. Nonetheless, the process of financial liberalisation which saw the removal of bank liquidity ratios to control bank lending, a loss of bank lending business to the unregulated non-bank financial sector, and the elimination of constraints on bank deposit and loan rates contributed to a decline in the quality of credit screening and monitoring and a major banking crisis. As was the case in the East Asian and Chilean examples cited, the Swedish banking crisis was

Jonung (1986), p. 116. See Englund (1990) on financial deregulation in Sweden.

32 Lindgren (1990), p. 264.

33 It should be mentioned that historically the large banks in Sweden have had quite good systems of credit analysis and loan performance monitoring. 
in part the result of insufficient supervision and prudential regulation of both banking and non-bank financial intermediaries. ${ }^{34}$ The financial supervisory technology necessary to survive in a deregulated environment was in many cases simply not there.

\subsection{Market assessment of banking system health: the weakness of market discipline}

The previous sections suggest that the underlying weakness of several East Asian countries' banking systems were in some regards not unlike the vulnerability seen in the past in Latin American countries and several industrial countries once financial liberalisation took place. The delayed evolution of the financial supervisory and prudential regulatory functions appear time and again, ignored during periods of prosperity and growth and only addressed once severe financial crisis emerges.

This lack of attention to improved financial oversight is surprising given the difficulty the market has in evaluating the quality of banking institutions and the risk this poses to financial stability, adding to the potential threat presented by a new competitive financial environment.

Evidence that markets have considerable problems in evaluating the quality of banking institutions is available in the study by Randall (1989) on the ability of investors and security analysts to identify the quality of US bank holding companies in the 1980s, before these institutions got into difficulty. Randall presents evidence to suggest that both the equity market and bond rating agencies were unable to identify the credit problems of large US bank holding companies until it was too late. His evidence casts considerable doubt on the ability of market discipline alone to limit the credit risk intermediaries take on.

Consider the equity market assessment of the quality of banks in East Asian countries before the recent crisis. Bank shares in Indonesia and Malaysia consistently performed better than their respective overall equity index during the 1990s, then fell precipitously in 1997, as seen in Chart 7. In Thailand both the overall index and the bank share index increased strongly during the 1990s and fell together from 1997. Only in Korea did it appear that the equity market may have been signalling some weakness in the banking system.

It is also noteworthy that a survey of country risk seen through the eyes of leading banks, conducted by Institutional Investor, failed to signal major problems in East Asia immediately before the financial crises (Table 3: between 75 and 100 banks were asked to rate countries on a scale of 0 to 100; they were not allowed to rate their own country; the responses were weighted by Institutional Investor

34 Drees and Pazarbasioglu (1998) provide a good overview of financial liberalisation in the Nordic countries. 
Chart 7

Stock market indices: total market and banks

Weekly averages $-1995=100$

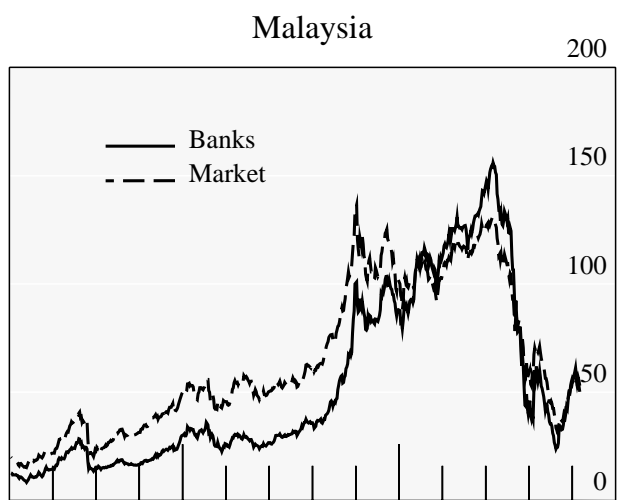

Indonesia
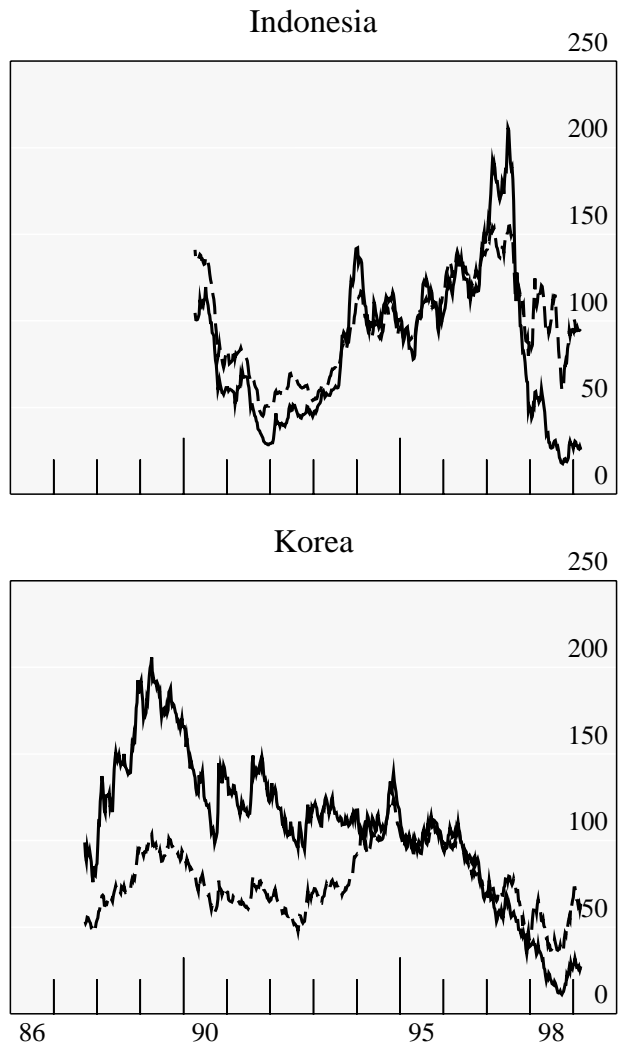

Thailand

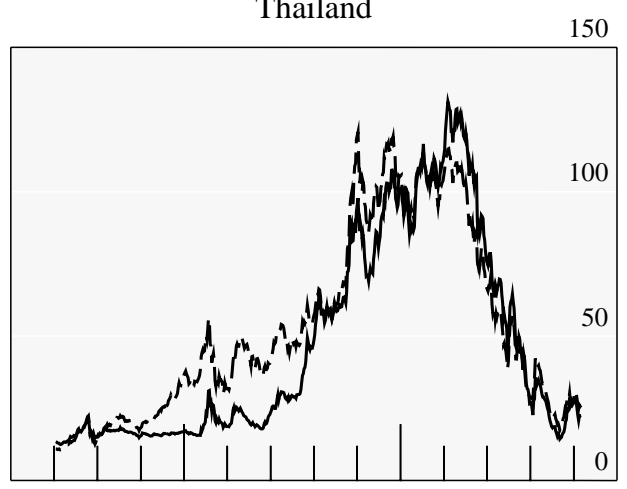

Philippines

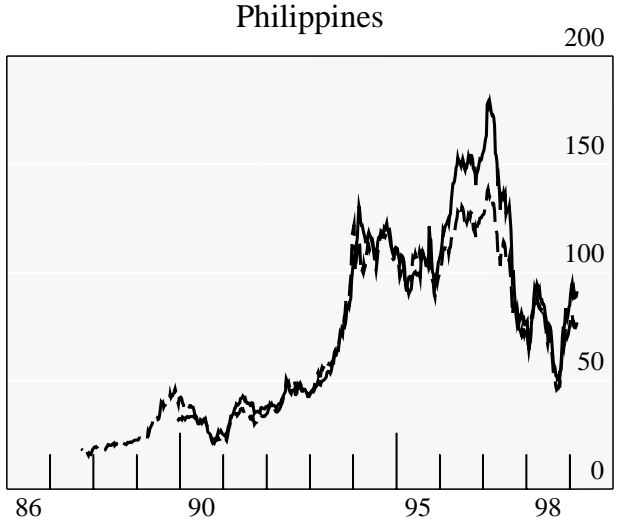

Source: Datastream 
Chart 8

Stock market indices: property companies

Weekly averages $-1995=100$
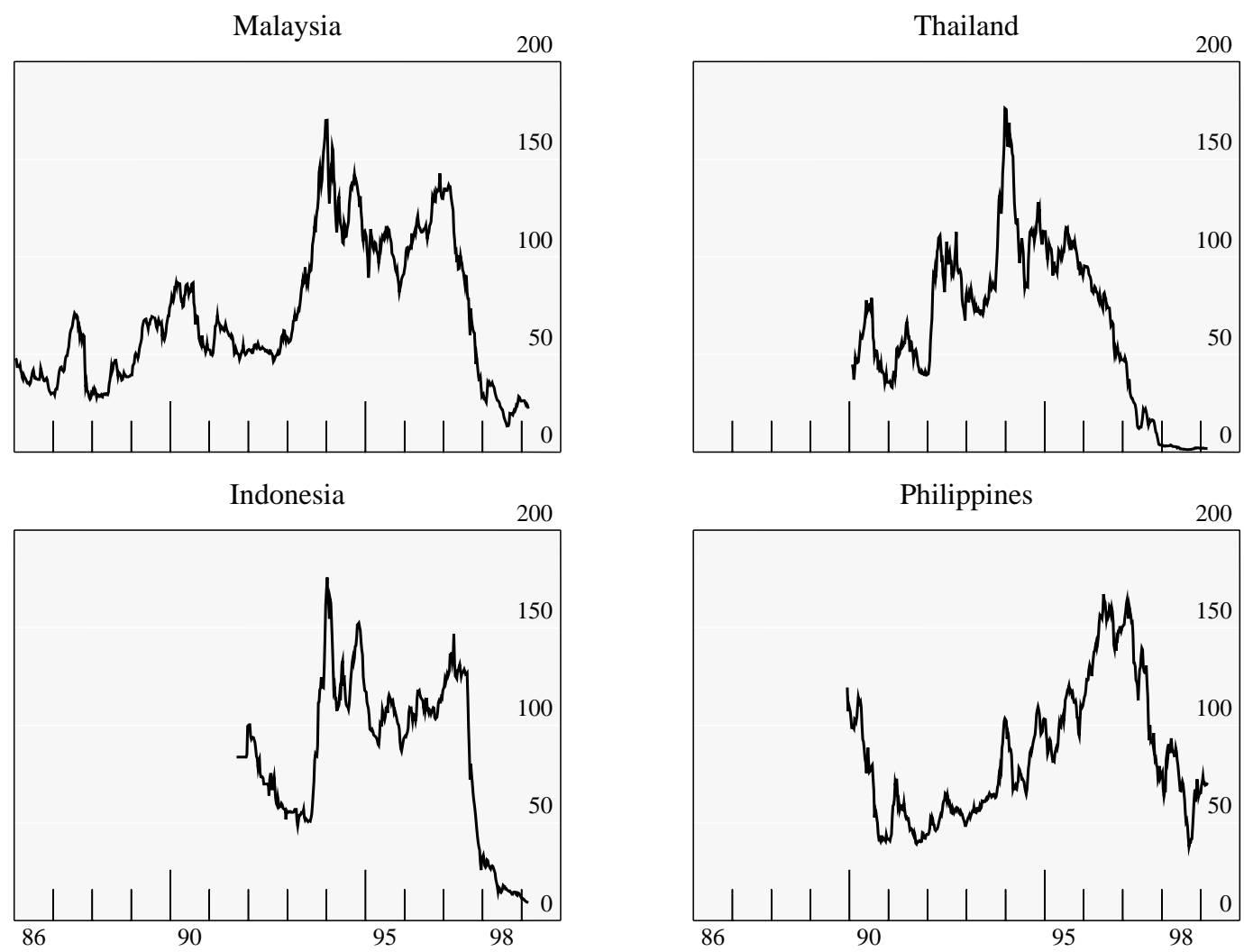

Source: Datastream 
Table 3

Institutional Investors' Country Credit Ratings

\begin{tabular}{|c|c|c|c|c|c|c|c|c|c|c|}
\hline \multirow[t]{2}{*}{ Country } & \multirow{2}{*}{$\begin{array}{c}\text { September } \\
1994\end{array}$} & \multirow{2}{*}{$\begin{array}{c}\text { September } \\
1995\end{array}$} & \multirow{2}{*}{$\begin{array}{c}\text { March } \\
1996\end{array}$} & \multirow{2}{*}{$\begin{array}{c}\text { September } \\
1996\end{array}$} & \multirow{2}{*}{$\begin{array}{c}\text { March } \\
1997\end{array}$} & \multirow{2}{*}{$\begin{array}{c}\text { September } \\
1997\end{array}$} & \multirow{2}{*}{$\begin{array}{c}\text { March } \\
1998\end{array}$} & \multicolumn{3}{|c|}{ Statistics* } \\
\hline & & & & & & & & Mean & $\begin{array}{l}\text { Standard } \\
\text { Deviation }\end{array}$ & Max/Min. \\
\hline Hong Kong & 66.1 & 67.0 & 65.4 & 65.3 & 64.9 & 63.9 & 62.9 & 68.4 & 4.3 & 77.9 / 62.9 \\
\hline Indonesia & 51.5 & 52.4 & 51.8 & 52.2 & 51.6 & 51.8 & 49.9 & 50.4 & 3.7 & $57.4 / 42.9$ \\
\hline Malaysia & 67.6 & 69.1 & 68.4 & 67.7 & 67.5 & 66.7 & 64.5 & 64.9 & 5.6 & $73.8 / 54.4$ \\
\hline Mexico & 46.1 & 41.8 & 41.2 & 41.6 & 42.6 & 43.5 & 45.2 & 42.7 & 12.5 & $73.0 / 27.1$ \\
\hline Philippines & 32.9 & 36.8 & 38.1 & 40.5 & 42.3 & 44.3 & 43.3 & 31.0 & 8.9 & $48.4 / 18.4$ \\
\hline Singapore & 81.8 & 84.0 & 82.8 & 83.7 & 83.9 & 84.2 & 82.9 & 78.9 & 2.9 & $84.2 / 73.8$ \\
\hline South Korea & 70.0 & 72.2 & 72.0 & 72.1 & 71.4 & 69.7 & 64.4 & 64.0 & 6.0 & $72.2 / 54.5$ \\
\hline Thailand & 62.2 & 63.8 & 63.4 & 63.2 & 61.1 & 59.9 & 52.3 & 57.1 & 4.7 & $63.8 / 50.6$ \\
\hline
\end{tabular}

* March 1980 to March 1998. 
according to the individual bank's worldwide exposure and the sophistication of its country risk analysis.) $)^{35}$ Among the downgrades between March 1996 and March 1997 stood Thailand, Taiwan, Malaysia and South Korea in that order, but with only Thailand displaying a large negative revision. Indeed, the overall international investment climate in the eyes of banks was quite sanguine. In March 1997, the global average country credit risk rating rose to its highest level since September 1986. The picture was bright enough for the Institutional Investor survey writer to conclude that for many countries "they are turning back the clock to an earlier era, when international finance seemed highly promising and less risky, when everyone knew Walter Wriston was right when he implied that countries do not go broke". ${ }^{36}$

\subsection{Harberger redux}

Fourteen year old Harberger (1985a and 1985b) makes good reading in the aftermath of the East Asian crisis. In allocating the blame for the Chilean crisis of 1981-84 his strongest criticism was reserved for policymakers. It rested with their failure to enforce "rigorous vigilance" over the behaviour of Chilean banks. ${ }^{37}$

It pays to note how many similarities there are between the Chilean experience of the early 1980s and the current East Asian crisis. After a large downturn in 1975 partly due to fiscal tightening, real GDP increased by almost $8 \%$ for the next five years. Growth weakened, but only modestly, in 1981. Chile fixed its exchange rate in 1979 at 39 pesos to the dollar. Harberger argued, however, that the Chilean peg of the dollar was not the fundamental source of the crisis.

A central vulnerability was the banking system. After 1973 a large number of Chilean firms were returned to the private sector, many sold at auction. A good number were in a weak financial condition. As banks began to accumulate bad loans they were extremely reluctant to take write-offs because of the damage it could cause to their capital position and hence to their competitiveness. Much of the credit demand during the 1975-82 period was artificial, used to roll over debt, with the effect of crowding out legitimate credit demands and keeping real interest rates high. When eight financial institutions got into trouble in 1981, four of which were banks, they were bailed out; both depositors and other creditors were made whole. This was in keeping with the bailout of Banco Osorno several years earlier. Harberger argued forcefully that these earlier bailouts were the argument used by the

\footnotetext{
35 See Shapiro (1997) for a discussion of country risk ratings before the East Asian crisis.

36 ibid., p. 201.

37 Harberger's arguments were not ignored by everyone in East Asia. Park (1991) repeats Harberger's claim that the Chilean crisis could have been avoided with better banking regulation. Velasco (1991) provides a comprehensive overview of the Chilean liberalisation and crisis between 1975 and 1985. He argues that the interlocking ownership arrangements between firms and banks were the root source of the excessive loan growth and the ultimate financial collapse in Chile.
} 
international banking community to request a bailout of almost the entire banking when the crisis hit its peak in January 1983. The government then provided guarantees for all foreign debts of the Chilean banking system. By 1985 more than $70 \%$ of the banking system was controlled by the government.

Before the crisis Chile was viewed as the "darling" of the international banking community, much as several Asian countries were recently. With this darling status came an inflow of foreign capital. Earlier regulations on capital inflows - for example, on the amount and maturity of Chilean bank borrowing from foreigners - were relaxed in 1980, leading to a large inflow of capital in 1981. Few argued against this relaxation. Harberger also points his finger at the "zeal" of international bankers lending to Chile, who appeared to ignore the risk in Chilean bank portfolios. For a time Chilean bankers were borrowing at 62.5 basis points above LIBOR in the international interbank market.

Observing the questionable quality of the assets on the books of Chilean banks, the size and cost of their borrowing from abroad, one might have expected the Chilean Superintendency of Banks to step in. This did not occur with any force. Had Banco Osorno not been bailed out, Harberger suggests that both Chilean banks and the international banking community might have acted more cautiously. ${ }^{38}$ His final lament in 1985 might be applied with equal force to the current difficulties of East Asia. "Few who have witnessed the banking disasters of Chile, Mexico and Argentina ... can doubt that the supervision of banks is indeed a most serious and important responsibility of economic policy" (p. 248).

Harberger's admonishments regarding dangerous moral hazard precedents and lax bank supervision have been repeatedly ignored by governments pushing to deregulate their financial systems. The excessive momentum to deregulate has often met with considerable inertia in seriously improving prudential regulation and supervision of aggressively competitive banking systems. The recent review of the Nordic banking crisis by IMF economists highlights the "little emphasis" the Nordic countries placed on reinforcing supervisory oversight of the financial system after deregulation. ${ }^{39}$ Indeed, in some cases the quality of the oversight of the banking system worsened after deregulation. The supervisory officials in Finland and Norway reduced on-site bank examinations, emphasising supervision by documentation. In Norway and Sweden more attention was paid to the status of capital

38 The Chilean experience of the 1980s has not been forgotten - at least not in Chile. Le-Fort (1994) argues that three conditions made the Chilean financial system vulnerable and potentially subject to crisis: (1) implicit deposit insurance made depositors (domestic and foreign) ignore portfolio risk; moreover, the government did not regulate and supervise banks because the authorities felt this should be left to the market; (2) excessive growth optimism deflected concern with levels of indebtedness; and (3) some of the major banks were members of large conglomerates, their capital was marginal and the banks were used to grant loans to enterprises within the conglomerate, at rates and conditions to the disadvantage of the bank. Some of these conditions also existed in Asian countries currently in crisis. In the 1986 Chilean banking law reform the Superintendency of Banks and Financial Institutions was required to publish in the press each year the condition of individual banking institutions. Another major change in banking law was in the requirements for bad loan provisioning.

39 See Drees and Pazarbasioglu (1998). 
market improvement and less to the quality of bank risk management in the newly deregulated environment.

Thirteen years after Harberger's assessment of "what went wrong in Chile?", we now have the question being asked of East Asia. The response might be the same, namely that "Chile could well not have found herself in a bad problem, starting in mid-1981, had the banks been better regulated". And in fact it is. The Bank of Korea now admits that "no strict examination was carried out on the scale of non-performing loans of the non-bank financial institutions, whose business conditions were no better and often worse than the banks", ${ }^{40}$

It is incorrect to suggest that all the countries currently enmeshed in financial crisis in East Asia had completely inefficient systems of prudential regulation and supervision. After earlier crises a number of countries had attempted to restructure and strengthen their financial oversight function. However, even where major improvements in bank supervision and regulation have occurred, doubt may remain about the ability of financial intermediaries to sustain a sudden external shock. For example, after Argentina put in place its currency board monetary arrangement in 1991 it strengthened its bank regulation and supervision. This included a reorganisation of bank supervision at the central bank, the adoption of a US-type "CAMEL" rating system for banks and reinforced capital standards. Nonetheless, problems with provincial banks remained and were well known. When the Mexican devaluation occurred it took only the liquidity problems of a small bond trader to trigger financial panic. $^{41}$

It is not a wasted effort to recall the number of banking crises since 1980 which have had inadequate prudential supervision as an underlying cause. According to a World Bank review of banking crises, inadequate prudential regulation played a leading role in: Hong Kong, 1982-83; Japan, 1991; Chile, 1981-93; the Philippines, 1981-87; Turkey, 1982-85; the United States, 1979-89; to name just a few. ${ }^{42}$ The weakness of financial oversight in East Asia was well known. In 1992 the IMF drew attention to the rapid growth and modest regulation of non-bank financial intermediaries in Korea. ${ }^{43}$ In 1995 it pointed to the absence of adequate regulation and supervision in the APEC developing countries. ${ }^{44}$ At the same time, some remained uncritical of the quality of banking supervision in East Asia. As

\footnotetext{
40 The Bank of Korea (1998), p. 10.

41 See Garcia-Herrero (1997) for details.

42 World Bank (1993), pp. 249-51.

43 Bisat, Johnston and Sundararajan (1992), p. 55.

44 Folkerts-Landau et al. (1995).
} 
recently as 1996 Stiglitz and Yu (1996, p. 258) suggested that, with the exception of Indonesia, central banks in East Asia had performed a "good job" of supervising commercial bank loan portfolios. ${ }^{45}$

\subsection{Short-term capital flows and financial immaturity}

The history of financial development since the 1970s provides enough examples of financial liberalisation, rapid credit growth and asset price booms, followed by asset price collapse, for us to understand some of the origins of financial crisis. One of the triggers has been a large turnaround in international short-term capital flows. In the East Asia crisis we have seen a reversal of private capital flows for the five countries in difficulty of the order of $\$ 109$ billion between 1996 and 1997, from a net inflow of $\$ 97$ billion to a net outflow of around $\$ 12$ billion (Institute of International Finance estimate). Such reversals have at times been in response to a rapid change in perceptions regarding the health of the financial system and the ability of the government to come to its aid.

A financial system with severe moral hazard problems may provide a put option to owners of financial intermediaries, particularly if they are large and politically well-connected. It presents an opportunity for individual initiatives in the financial system to prosper from success, while having losses shouldered by the government in the event of failure. Equity holders in some financial systems are able to exploit the weak information and control position of creditors and financial authorities. The incentive is for the intermediaries to take on greater risk than they might otherwise.

The regulatory, information and corporate control conditions in a number of developing country financial systems often make intermediaries prime candidates for exploitation, or, as some have called it, "looting" or "go-for-broke" investment strategies. ${ }^{46}$ There are a number of reasons why such behaviour may arise, many having to do with a macroeconomic objective of the government which permits private market participants to exploit a particular government vulnerability. In some cases it involves the government's desire to fix or stabilise some particular price (e.g. the exchange rate) or provide a blanket guarantee to insure stability because of severe information asymmetries in the financial system (e.g. deposit insurance). As developed by Akerlof and Romer (1993), the incentive for looting occurs because the government establishes an inefficient contract which private market participants attempt to exploit, such as non-risk-based deposit insurance. The frequently cited example of this behaviour is that of the management of a number of savings and loan associations in the United States during the 1980s.

45 Stiglitz and Yu (1996, p. 272) suggest that it was "remarkable" that East Asian governments took action to address financial market failure, "such as prudential regulation", at an earlier stage of development than that seen in industrial countries.

46

Akerlof and Romer (1993) provide a simple model of looting and go-for-broke strategies, together with several interesting examples. Krugman (1998a) picks up on this theme to analyse the Asian financial crisis. 
The incentive for intermediaries to exploit new opportunities provided by a more liberalised financial system is enhanced once a country has access to international capital markets. It is difficult to judge when a country is "mature" enough to permit it access to foreign capital. But it is clear what the incentive is. As Akrasansee (1998) has stated in the case of Thailand, "the argument is very simple. International capital is cheap". Despite several previous crises originating in part with large foreign short-term capital inflows, during the 1990s most emerging market countries have been reluctant to heed Harberger's (1985a) lesson from the Chilean experience of the 1980s, that some flexible restrictions on capital inflows may be desirable. ${ }^{47}$ The near-term advantages of less expensive foreign borrowing, even for countries with high saving rates, usually outweigh the distant risk of capital flight.

Encouraged by large Thai interest rate differentials over foreign rates, short-term capital flooded into Thailand in recent years, much of it through the Bangkok International Banking Facilities (BIBFs). Established in 1993, the BIBFs were composed of 45 banks, 34 of which were foreign. They provided private institutions with ready access to foreign short-term financing at favourable rates. According to BIS statistics, total gross international claims of foreign banks on Thailand grew from almost $\$ 23$ billion in 1992 to $\$ 70$ billion in 1996. A fixed exchange rate meant that market participants faced no exchange risks, at least until the crisis erupted.

Thai officials admitted that their capital markets were seriously underdeveloped, with little depth in the equity market and an almost non-existent long-term bond market. ${ }^{48}$ The high level of private market confidence after several years of strong real growth appeared to relax concern over foreign indebtedness, although the Bank of Thailand was clearly worried about the large sums of foreign capital being funnelled into the real estate sector.

Thailand was not alone in availing itself of plentiful foreign capital. Several East Asian countries increased their international indebtedness by large amounts (Chart 9 and Table 4). The shift in the composition of external financing from foreign equity investment to bond and especially foreign bank financing increased the vulnerability of these countries, particularly as much of the foreign bank financing was short-term and foreign currency denominated. What is notable in the financing patterns of East Asian countries is the large amount of interbank borrowing, as seen in Table 4. For example, in $199665 \%$ of Korea's gross foreign bank debt was interbank. ${ }^{49}$ The size of the short-term foreign

47 Krugman (1998b) is one of the few academics to consider the potential desirability of exchange controls to permit lower interest rates in East Asia. Governor Gramlich (1998) of the Federal Reserve admits to there being "occasional instances" when some capital flow restrictions may be justified. Akrasanee (1998).

49 See Bank for International Settlements (1998), Chapter VII, for a discussion of financial intermediaries and the Asian crisis. Much of this analysis reflects the work of Philip Turner. 


\section{Chart 9}

\section{Selected Asian financial indicators}

Bilateral exchange rate (versus US dollar)

Real effective exchange rate

(end-1993 = 100)

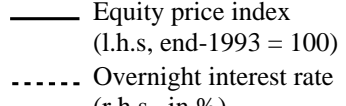

Overnight interest rate

(r.h.s., in \%)

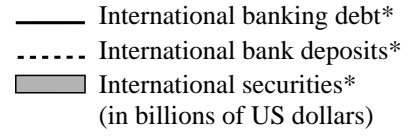

Indonesia
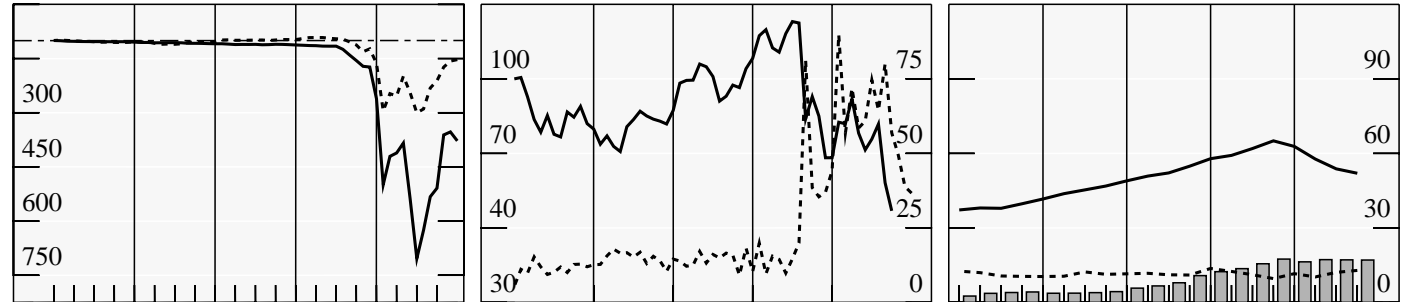

Malaysia
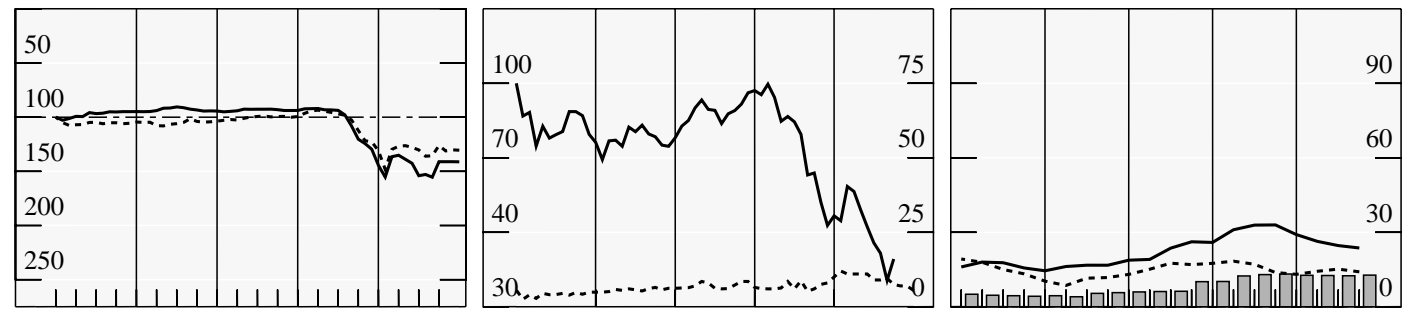

Philippines
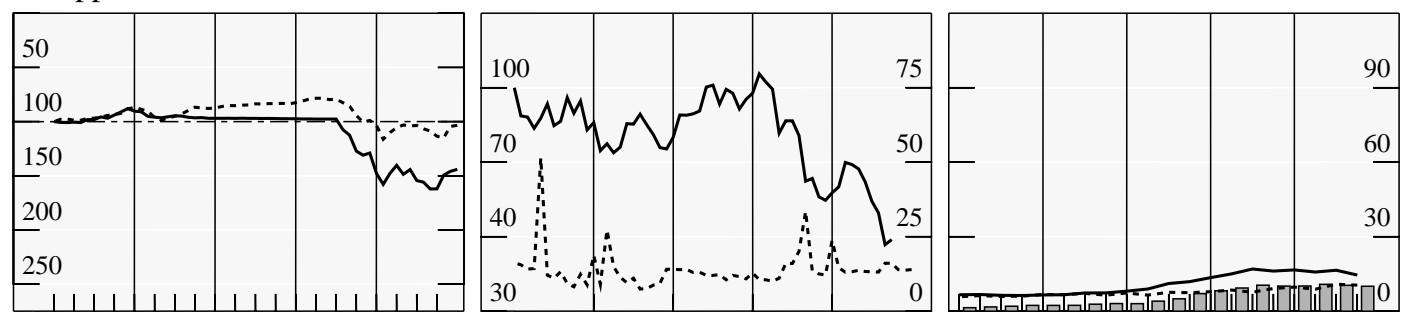

South Korea
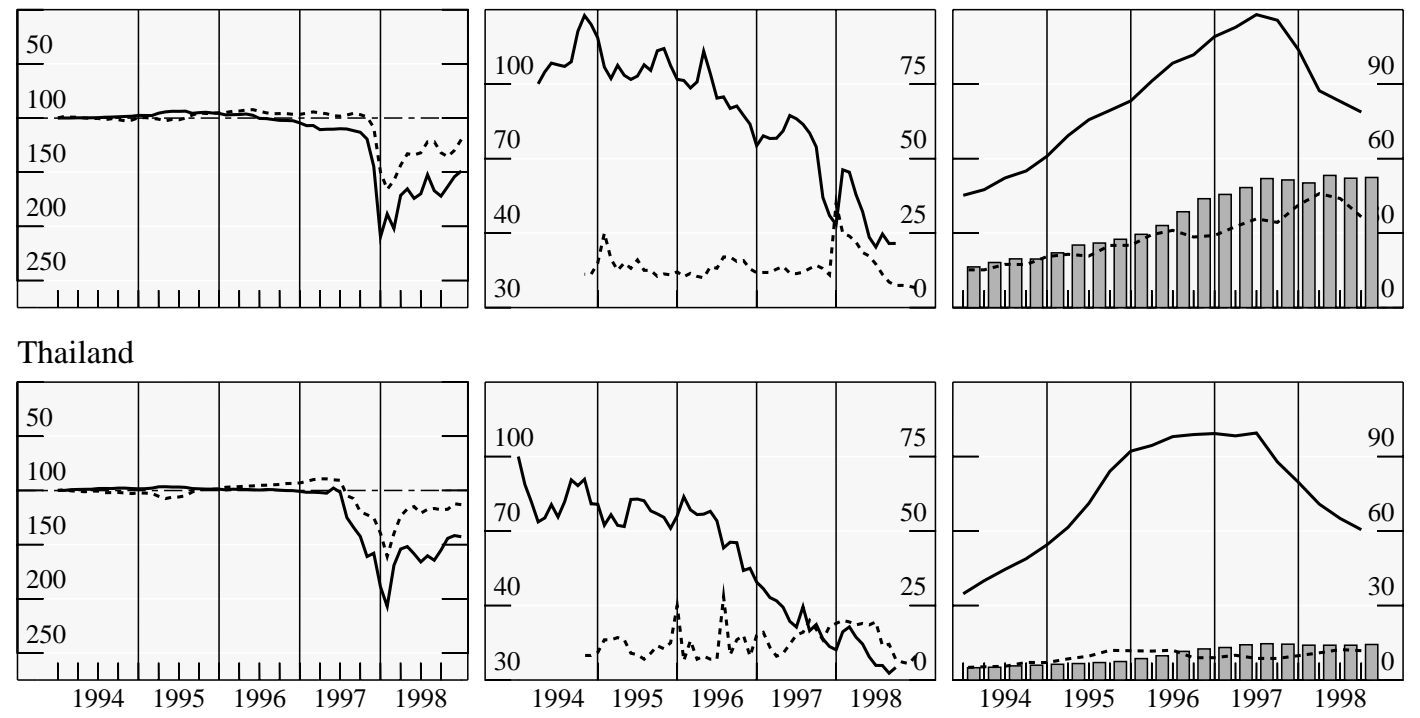

* Stocks outstanding.

Sources Bank of England, Bloomberg, Datastream, Euroclear, Euromoney, IFR, IMF, ISMA, national data and BIS. 
Liquidity, equity prices and bank lending to the emerging markets

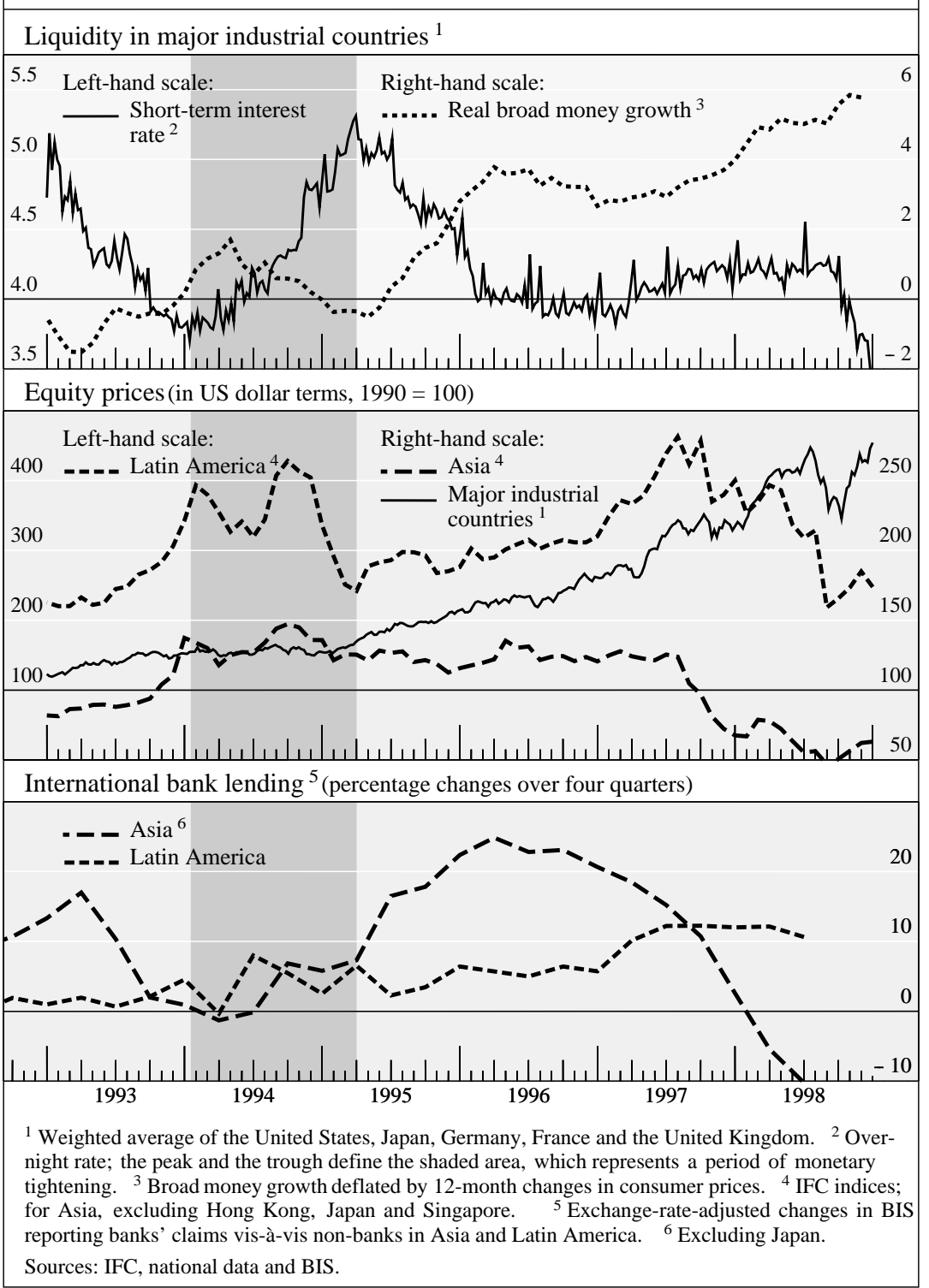

currency funding in East Asian countries and the underdeveloped nature of their capital and money markets suggested a vulnerability to an international liquidity squeeze. 
Table 4

Maturity distribution of total gross international claims of foreign banks on selected East Asian and Latin American countries

In billions of US\$ at end-year

\begin{tabular}{|c|c|c|c|c|c|c|c|}
\hline & Total claims & $\begin{array}{l}\text { Up to and } \\
\text { including one } \\
\text { year }\end{array}$ & $\begin{array}{c}\text { Over one year } \\
\text { up to two } \\
\text { years }\end{array}$ & $\begin{array}{l}\text { Over two } \\
\text { years }\end{array}$ & Unallocated & $\begin{array}{c}\text { Up to and } \\
\text { including one } \\
\text { year as a \% } \\
\text { of total }\end{array}$ & $\begin{array}{l}\text { Interbank } \\
\text { claims }\end{array}$ \\
\hline & \multicolumn{7}{|c|}{ INDONESIA } \\
\hline 1990 & 24.7 & 13.4 & 2.2 & 8.0 & 1.0 & 54.5 & 5.0 \\
\hline 1991 & 27.3 & 15.1 & 3.2 & 7.9 & 1.1 & 55.2 & 5.8 \\
\hline 1992 & 28.3 & 17.2 & 2.4 & 7.6 & 1.1 & 60.7 & 6.5 \\
\hline 1993 & 30.5 & 18.8 & 2.7 & 8.1 & 0.9 & 61.7 & 7.5 \\
\hline 1994 & 34.2 & 21.1 & 3.3 & 8.7 & 1.0 & 61.8 & 7.8 \\
\hline 1995 & 44.8 & 27.9 & 3.2 & 12.3 & 1.4 & 62.3 & 9.8 \\
\hline 1996 & 55.5 & 34.2 & 3.6 & 15.3 & 2.4 & 61.7 & 11.8 \\
\hline \multirow[t]{2}{*}{1997} & 58.4 & 35.4 & 3.7 & 17.3 & 2.0 & 60.6 & 11.7 \\
\hline & \multicolumn{7}{|c|}{ KOREA } \\
\hline 1990 & 28.7 & 20.4 & 1.4 & 5.8 & 1.2 & 70.9 & 15.4 \\
\hline 1991 & 34.2 & 23.9 & 1.9 & 6.8 & 1.6 & 69.8 & 20.1 \\
\hline 1992 & 37.7 & 26.6 & 2.2 & 6.5 & 2.4 & 70.7 & 23.4 \\
\hline 1993 & 41.2 & 29.2 & 2.4 & 7.0 & 2.7 & 70.8 & 26.0 \\
\hline 1994 & 56.5 & 40.1 & 2.9 & 8.1 & 5.4 & 71.0 & 37.0 \\
\hline 1995 & 77.3 & 54.1 & 2.6 & 12.0 & 8.6 & 70.0 & 52.2 \\
\hline 1996 & 100.0 & 67.5 & 4.1 & 15.9 & 12.5 & 67.5 & 65.9 \\
\hline \multirow[t]{2}{*}{1997} & 94.2 & 59.5 & 5.2 & 16.4 & 13.1 & 63.1 & 56.0 \\
\hline & \multicolumn{7}{|c|}{ MALAYSIA } \\
\hline 1990 & 7.3 & 2.1 & 0.5 & 3.6 & 1.1 & 28.3 & 1.0 \\
\hline 1991 & 7.8 & 3.0 & 0.6 & 3.2 & 1.1 & 37.9 & 2.0 \\
\hline 1992 & 8.5 & 4.1 & 0.3 & 3.2 & 0.9 & 48.1 & 2.9 \\
\hline 1993 & 13.0 & 7.4 & 0.6 & 4.0 & 1.0 & 56.8 & 5.2 \\
\hline 1994 & 13.5 & 6.6 & 0.8 & 4.8 & 1.2 & 48.8 & 3.9 \\
\hline 1995 & 16.3 & 7.9 & 1.1 & 5.7 & 1.6 & 48.2 & 4.3 \\
\hline 1996 & 22.2 & 11.2 & 0.7 & 7.3 & 3.0 & 50.3 & 6.5 \\
\hline \multirow[t]{2}{*}{1997} & 27.5 & 14.6 & 0.9 & 9.4 & 2.6 & 53.1 & 9.9 \\
\hline & \multicolumn{7}{|c|}{ PHILIPPINES } \\
\hline 1990 & 9.3 & 3.2 & 0.4 & 5.3 & 0.4 & 34.3 & 1.9 \\
\hline 1991 & 8.7 & 3.2 & 0.4 & 4.7 & 0.5 & 36.8 & 2.0 \\
\hline 1992 & 6.9 & 3.1 & 0.2 & 3.0 & 0.5 & 45.7 & 1.5 \\
\hline 1993 & 5.8 & 2.4 & 0.2 & 2.8 & 0.4 & 40.8 & 1.2 \\
\hline 1994 & 6.6 & 3.1 & 0.2 & 2.9 & 0.3 & 47.1 & 1.7 \\
\hline 1995 & 8.3 & 4.1 & 0.3 & 3.4 & 0.5 & 48.9 & 2.3 \\
\hline 1996 & 13.3 & 7.7 & 0.6 & 4.1 & 0.9 & 58.2 & 5.2 \\
\hline 1997 & 19.7 & 11.9 & 0.4 & 6.3 & 1.1 & 60.4 & 8.9 \\
\hline
\end{tabular}


Table 4 (continued)

\begin{tabular}{|c|c|c|c|c|c|c|c|}
\hline & Total claims & $\begin{array}{l}\text { Up to and } \\
\text { including one } \\
\text { year }\end{array}$ & $\begin{array}{c}\text { Over one year } \\
\text { up to two } \\
\text { years }\end{array}$ & $\begin{array}{c}\text { Over two } \\
\text { years }\end{array}$ & Unallocated & $\begin{array}{c}\text { Up to and } \\
\text { including one } \\
\text { year as a \% of } \\
\text { total }\end{array}$ & $\begin{array}{l}\text { Interbank } \\
\text { claims }\end{array}$ \\
\hline & \multicolumn{7}{|c|}{ THAILAND } \\
\hline 1990 & 13.6 & 8.8 & 0.7 & 3.7 & 0.4 & 64.7 & 4.5 \\
\hline 1991 & 19.5 & 13.0 & 1.3 & 4.6 & 0.6 & 66.8 & 5.2 \\
\hline 1992 & 22.9 & 15.8 & 1.3 & 4.8 & 1.0 & 69.1 & 6.5 \\
\hline 1993 & 29.6 & 21.4 & 1.8 & 5.7 & 0.7 & 72.1 & 8.9 \\
\hline 1994 & 43.4 & 30.8 & 2.0 & 9.3 & 1.3 & 71.0 & 14.1 \\
\hline 1995 & 63.0 & 43.8 & 3.5 & 13.6 & 2.0 & 69.6 & 20.8 \\
\hline 1996 & 70.1 & 45.7 & 4.8 & 16.3 & 3.3 & 65.2 & 25.9 \\
\hline \multirow[t]{2}{*}{1997} & 58.9 & 38.8 & 4.2 & 13.8 & 2.1 & 65.9 & 17.8 \\
\hline & \multicolumn{7}{|c|}{ ARGENTINA } \\
\hline 1990 & 26.1 & 7.1 & 0.5 & 18.0 & 0.5 & 27.1 & 6.6 \\
\hline 1991 & 26.5 & 10.0 & 1.0 & 14.9 & 0.6 & 37.8 & 6.0 \\
\hline 1992 & 30.3 & 14.4 & 1.4 & 13.4 & 1.0 & 47.6 & 7.2 \\
\hline 1993 & 30.0 & 15.7 & 0.7 & 11.9 & 1.7 & 52.3 & 5.3 \\
\hline 1994 & 35.3 & 19.0 & 1.7 & 12.2 & 2.5 & 53.7 & 6.8 \\
\hline 1995 & 38.3 & 21.7 & 2.2 & 11.1 & 3.3 & 56.5 & 8.3 \\
\hline 1996 & 44.8 & 25.2 & 3.0 & 12.7 & 3.9 & 56.3 & 8.8 \\
\hline \multirow[t]{2}{*}{1997} & 52.4 & 28.7 & 2.6 & 16.8 & 4.3 & 54.8 & 11.8 \\
\hline & \multicolumn{7}{|c|}{ BRAZIL } \\
\hline 1990 & 55.5 & 22.2 & 3.1 & 29.4 & 0.8 & 40.0 & 16.9 \\
\hline 1991 & 48.8 & 21.0 & 5.3 & 21.5 & 1.0 & 43.1 & 17.4 \\
\hline 1992 & 51.3 & 24.9 & 4.7 & 19.6 & 2.1 & 48.6 & 18.5 \\
\hline 1993 & 54.0 & 29.4 & 3.5 & 18.7 & 2.4 & 54.5 & 20.4 \\
\hline 1994 & 50.3 & 25.3 & 1.4 & 19.1 & 4.4 & 50.4 & 16.3 \\
\hline 1995 & 57.4 & 32.1 & 3.4 & 16.2 & 5.7 & 55.9 & 17.7 \\
\hline 1996 & 67.9 & 42.8 & 3.2 & 15.7 & 6.3 & 63.0 & 21.0 \\
\hline \multirow[t]{2}{*}{1997} & 76.4 & 49.0 & 2.7 & 19.8 & 4.9 & 64.1 & 27.1 \\
\hline & \multicolumn{7}{|c|}{ MEXICO } \\
\hline 1990 & 50.4 & 18.1 & 1.2 & 28.3 & 2.9 & 35.8 & 6.0 \\
\hline 1991 & 55.3 & 23.0 & 1.6 & 27.8 & 2.9 & 41.6 & 8.4 \\
\hline 1992 & 53.8 & 22.8 & 1.7 & 27.8 & 1.6 & 42.4 & 11.3 \\
\hline 1993 & 55.5 & 26.1 & 2.3 & 25.4 & 1.6 & 47.0 & 14.7 \\
\hline 1994 & 64.0 & 33.0 & 2.1 & 25.3 & 3.6 & 51.6 & 16.4 \\
\hline 1995 & 57.2 & 26.0 & 3.4 & 22.8 & 5.0 & 45.5 & 11.5 \\
\hline 1996 & 60.1 & 26.9 & 4.0 & 22.3 & 7.0 & 44.7 & 11.7 \\
\hline 1997 & 61.8 & 27.6 & 2.5 & 25.6 & 6.1 & 44.6 & 13.6 \\
\hline
\end{tabular}

For most of the five East Asian countries currently in difficulty, dependence on short-term foreign funding was a relatively recent phenomenon. The reasons for resorting to such enormous amounts of foreign financing differ by country. In Malaysia, for example, one contributing factor may have been the government's attempt to build a regional financial centre. In addition, the ready availability of foreign short-term funds/credit contributed in some cases to "the development of get-rich-quick, 
casino mentality which led to the diversion of resources from productive activities toward speculative ones", according to Piei and Ariff (1998).

In Korea the relaxation of controls on foreign borrowing in the 1990s took place without adequate supervision, particularly of merchant banks. ${ }^{50}$ Unable to raise long-term capital because of inadequate credit ratings, merchant banks raised short-term foreign capital to fund long-term investments, resulting in a serious maturity misalignment. At one point $67 \%$ of their borrowing was short-term and 95\% of their lending long-term. Moreover, the Foreign Exchange Management Law restricted longterm foreign borrowing, while few restraints were placed on raising funds short-term.

Not unlike the earlier Nordic and Chilean banking crises, foreign capital inflows intermediated through the banking system were used to fuel a boom in asset prices, particularly in equity and real estate. Rising asset prices increased the value of collateral, inducing further lending by banks. The underdevelopment of local capital markets made hedging of long-term lending difficult. Further exposing the banks in several countries was the limited degree of bank portfolio diversification. The old cycle was repeated, this time in East Asia.

Certainly excessive lending for real estate and equity investment was not the only cause of the crisis in East Asia. Nonetheless, together with interconnected lending it was a feature shared with many earlier banking crises. A generic vulnerability has been the excess leverage in economic systems with long histories of government guarantees and therefore poor corporate control in both financial and nonfinancial sectors. The availability of low cost foreign short-term financing provided additional resources for further exploitation of the inefficient contracts the government had with the private sector.

The dynamic mechanism which increases leverage in newly liberalised financial systems often derives from the endogeneity of credit limits. Real assets used as collateral increase credit limits as their market value rises. This can spark the beginning of an asset price bubble, as financial liberalisation first relaxes credit constraints, leading to a demand for fixed assets, such as real estate, whose higher market price raises collateral values, further increasing credit availability, borrowing and asset prices. ${ }^{51}$ This dynamic multiplier of credit lines and asset values can become all the more rapid the poorer the quality of credit screening by intermediaries and the greater the number of new underinformed lenders, some entering as a result of capital account liberalisation.

Bank-funded property and equity investment provide lucrative private opportunities to increase the vulnerability of the government's guarantee of the liabilities of financial institutions. The difficulty of determining the fundamental value of real property and equity investments, particularly for an

\footnotetext{
50 See Kim and Rhee (1998).

51 A model of the dynamic interaction between credit limits and asset prices is presented in Kiyotaki and Moore (1997).
} 
economy with poor accounting, auditing and disclosure standards in a stage of rapid development, may further stimulate bank lending based on current market collateral values. In a competitive environment, with banks having recently been released from lending and funding constraints, the incentive to finance such investments often proves irresistible. It is not a purely academic question to ask whether international lending to some East Asian countries contributed to a run-up in corporate debt which had the characteristics, in the technical sense, of a "rational Ponzi game". 52 (Modern usage of this term does not refer to fraudulent behaviour, just as asset price bubbles do not.) At the end of 1997, for example, the 30 largest Korean conglomerates had an average debt-equity ratio of 519\%, compared with $86 \%$ in Taiwan, $193 \%$ in Japan and $154 \%$ in the United States. ${ }^{53}$ The Ponzi game characteristic of international lending is the perpetual rolling over of the debt by additional borrowing. In modern parlance, the game is "rational" in the sense that each loan has positive net present value for the borrower. (Each lender expects to be repaid with the arrival of a new creditor.) For this to be possible requires a continuous flow of new lenders into the market.

That a string of new international lenders would enter such a market is understandable when a country has grown rapidly for several years and where borrowers have for a long time enjoyed a considerable degree of government protection, as The Bank of Korea suggests large enterprises did in Korea. ${ }^{54}$ The heavy government protection of banks is said to have emboldened Korean banks to borrow short-term and invest long-term in South-East Asia and other emerging markets. It is somewhat of an exaggeration to claim that the East Asian crisis is different from earlier crises because of the heavy concentration of problem debt in the private sector. In some cases private debt with strong implicit government guarantees might just as well be considered quasi-sovereign obligations. In retrospect, it may not be such a surprise that international bank lending to Korea rose to such high levels in just a few years. At mid-1997, gross international claims of foreign banks on Korea totalled $\$ 104$ billion, of which $\$ 68$ billion was international interbank debt. As detailed by O'Connell and Zeldes (1988), to understand the ability to sustain Ponzi game credit equilibria in the international lending market it is necessary to focus on the conditions in the lenders' economies. ${ }^{55}$ These conditions were such that liquidity was ample, interest rates were low and one lender, the United States, was itself in a state of economic "euphoria" given several years of rapid growth.

\footnotetext{
52 See O'Connell and Zeldes (1988) on rational Ponzi games.

53 The Bank of Korea (1998), p. 12.

54 The Bank of Korea (1998) suggests that it was "an unwritten law" that "conglomerates will never go broke" (p. 11).

55 See O'Connell and Zeldes (1988), pp. 445-6. The perpetual rollover of debt "equilibrium" requires that the growth rate of the lending country exceeds the rate of growth of debt of the borrowing country.
} 


\section{Precarious credit equilibria}

\subsection{Reluctant disclosure and government risk-sharing}

If the East Asian financial crisis has taught us anything, it has taught us to be suspicious of any confidence we have in thinking we know what factors contribute to financial stability. It has taught us that sound macroeconomic fundamentals are not sufficient to prevent major banking crisis. Indeed, it should make us redefine what we consider to be "fundamentals" capable of sustaining a financial system through unexpected domestic and foreign asset price shocks. We have also learned that Goldsmith (1982) was off the mark when, in an attack on Minsky, he referred to financial crises as "a childhood disease of capitalism, not an affliction of old age". East Asia currently presents us with an example of a mature economy, Japan, suffering from a similar rude reversal of fortunes as five economies in much earlier stages of financial development, and partly for similar reasons. Here we focus briefly on the role of information in providing resiliency to a financial system.

Many of the banking crises of recent vintage have had as a contributing factor the absence of sound corporate governance of enterprises and intermediaries, whose components include rigorous accounting, auditing and disclosure requirements and efficient prudential regulations and supervision. Given their deficiency in some countries, we should first ask what the motives are for the underproduction of information. Secondly, we need to understand why depositors, in particular international lenders, were content to place funds with intermediaries whose behaviour was so difficult to monitor.

In several of both recent and past financial crises there has been evidence of wilful misrepresentation of the financial status of non-financial and financial enterprises. The inefficiency of external auditing and poor public disclosure is often observed even if intentional misrepresentation is not. The surprise failure of two large Japanese institutions, for example, earlier weakened public confidence in accounting, auditing and disclosure systems in Japan, creating credit risk concerns in the interbank market. ${ }^{56}$ Inadequate transparency has also been singled out as a primary cause of financial crisis in Korea. ${ }^{57}$ Financial crises are often first information crises.

Part of the blame for the lack of transparency of the financial status of some intermediaries rests with the regulators themselves. ${ }^{58}$ As elsewhere, government regulators of emerging market countries are not infrequently pursuing several goals, two of which are to assist with government macroeconomic

56 Fukao (1998) suggests that the mistrust of the internal auditing systems in Japan had caused concern over the execution of the fiduciary responsibilities of some intermediaries.

57 The Bank of Korea (1998), p. 9.

58 Kane (1998) emphasises the incentive conflicts of government regulators. Kane (1991) considers an incentive-based theory of financial regulation. 
objectives and desired credit allocations and to protect favoured financial intermediaries or sectors from aggressive competition, foreign institutions or capital markets. ${ }^{59}$ The underproduction of external information is often used as a protective device by financial and non-financial enterprises (against takeover, to secure favourable credit conditions), sometimes with the consent of regulators. Moreover, when intermediaries come under attack, opacity is sometimes used as a means of hiding their vulnerability in order to reduce the costs of restoring stability.

It would be naive to believe that depositors are completely unaware of this lack of transparency, or are completely uninformed of the quality of banking supervision and regulation. ${ }^{60}$ They are likely to be aware that both intermediaries and regulators may have strong motives to delay performance disclosure, provisioning and costly loan write-offs. We have seen this in developed countries as well. To compensate for deficiencies in external transparency, governments may extend both explicit and implicit guarantees to creditors. Limited transparency and government guarantees have permitted some non-financial firms to sustain, for a time, extraordinarily high debt equity ratios and enabled some banks to borrow heavily in the international interbank market. Government creditor guarantee systems thus can stabilise an inherently "underinformed" financial system for a time as long as the guarantee is credible. This credibility may be weakened, sometimes abruptly, if the market realises that the local authorities are increasingly concealing information.

No doubt some corporate governance structures in the past have worked well with modest external disclosure. Business information in a number of countries is closely held inside interdependent industry-bank networks cemented by large cross-shareholdings and systems of mutual risk-sharing. ${ }^{61}$ In some cases government regulators are part of this inside information network. However, this lack of transparency can also result in a dramatic overreaction by doubtful creditors, particularly where information is difficult to verify.

The crisis in East Asia is in many ways a crisis of corporate control and information structure. The underproduction of public information arguably may have been an element contributing to stability, both economic and political, as long as any excesses of the participants were not great enough to threaten the solvency of strategic members of the group, particularly banks, or threaten the credibility of the government's implicit guarantees. However, the weakness of public information and corporate

59 Calomiris (1998) quotes a former Chilean finance minister who describes how the Superintendency of Banks was restrained from providing an independent judgement of bank exposure to foreign exchange risk because of its potential conflict with macroeconomic policies.

60

Folkerts-Landau et al. (1995) pointed specifically to the weak supervisory and regulatory infrastructures in several of the APEC countries.

61 Fukao (1998) reports that at the end of September 1997 Sanwa Bank, Tokai Bank and Sakura Bank each held a $4.8 \%$ share in Toyota Motors, equal to $37 \%, 79 \%$ and $40 \%$ of the respective capital of these banks (at Toyota's share price of 12 February). Japanese law prohibits banks from owning more than $5 \%$ of the shares of one domestic company, but does not restrict the total amount of stock that is owned. 
governance structures in several East Asian countries contributed to the "overinvestment" by industrial firms and to the aggressive risk-taking by banks we now frequently see reference to. ${ }^{62}$ It also contributed to weak prudential oversight and to the ability of banks to delay provisioning and overstate their capital positions. ${ }^{63}$ The lack of transparency is now making the restoration of confidence more difficult.

\subsection{Unstable risk preferences and capital flow volatility: a stylised characterisation}

The Asian crisis illustrates once again that the incentives for the private sector of emerging market countries to build up large foreign currency exposures have not been matched by the incentives for governments to improve the transparency and rigorous oversight of their financial systems. ${ }^{64}$

An important question is why we did not earlier observe greater foreign lender "equilibrium credit rationing" in East Asia, as we might have expected given the information problems which existed and the potential unenforceability of some international claims. The factor which might help to explain this phenomenon is the role played by implicit government guarantees to lenders. ${ }^{65}$ The problem of asymmetric information in international credit markets appears to be ignored when a government's implicit guarantee is credible but amplified when, for some reason, the ability of the government to satisfy the implicit guarantee becomes doubtful. ${ }^{66}$ The deficiency of international borrower transparency, underemphasised in good "states of the world", can lead to a rapid exit of foreign lenders when either the guarantee is brought into question or the foreign lending institution itself is in difficulty and needs to retrench by calling in loans. The international banking market works surprisingly smoothly in one instance, given the information gaps, but suffers from extreme credit rationing in another, as if lenders cannot distinguish between good and bad borrowers. ${ }^{67}$ The result can be market failure and the rapid disappearance of liquidity.

62

In some cases banking reforms to correct these problems were made more difficult because banks were owned by or closely related to business conglomerates, as in Indonesia. See Nasution (1985).

63 See Bank for International Settlements (1998), pp. 118-21.

Korea, for example, known for having followed a gradual pace of financial liberalisation, saw gross foreign bank claims on the country rise from $\$ 28.7$ billion in 1990 to $\$ 100$ billion in 1996, of which two-thirds was interbank claims (BIS statistics). Net foreign debt grew by 33\% per year from 1994 to 1997, twice as fast as between 1979 and 1985 , when Korea last experienced serious financial difficulty (Kim and Rhee (1998), p. 21).

65

Diaz-Alejandro (1985, p. 8) conjectured that after the bailout of Banco Osorno in 1977, partly because of the authorities' concern with the possible impact of its failure on foreign lending to Chile, foreign creditors interpreted lending to the Chilean private sector as guaranteed by the state.

66

The credibility of implicit government guarantees is obviously difficult to judge. One measure might be, for example, Standard \& Poor's sovereign “contingent liability estimates", representing the potential peak of gross problematic assets in the financial system as a percentage of domestic credit to the private sector and non-financial public enterprises in the event of a worst-case recession. See Standard \& Poor's (1998b).

67 Recall that the early models of imperfect information credit markets, such as Jaffee and Russell (1976), emphasised the potential unstable nature of these markets and the possibility of their collapse. McKinnon (1991), Chapter 10, has argued that in the past both implicit guarantees in the debtor countries and deposit insurance and official export-import banks in the creditor countries caused both borrowers and lenders to ignore or underestimate normal credit risks. 
Table 5

International financial activity by residence or nationality of borrower

In billions of US dollars

\begin{tabular}{|c|c|c|c|c|c|}
\hline & 1997Q2 & 1997Q3 & 1997Q4 & 1998Q1 & 1998Q2 \\
\hline $\begin{array}{l}\text { Change in bank external assets vis-à-vis: } \\
\text { Developed countries } \\
\text { Developing countries } \\
\text { Of which: } \\
\text { Asia } \\
\text { Latin America } \\
\text { Eastern Europe }\end{array}$ & $\begin{array}{c}205.4 \\
25.2 \\
\\
15.8 \\
5.8 \\
3.3\end{array}$ & $\begin{array}{c}181.2 \\
18.0 \\
\\
-2.0 \\
10.7 \\
8.3\end{array}$ & $\begin{array}{c}454.1 \\
-7.1 \\
\\
-27.5 \\
10.2 \\
2.6\end{array}$ & $\begin{array}{c}-50.4 \\
-11.5 \\
\\
-33.7 \\
15.6 \\
6.5\end{array}$ & \\
\hline $\begin{array}{l}\text { Announced international syndicated } \\
\text { facilities for borrowers in: } \\
\text { Developed countries } \\
\text { Developing countries } \\
\text { Of which: } \\
\text { Asia } \\
\text { Latin America } \\
\text { Eastern Europe }\end{array}$ & $\begin{array}{c}308.0 \\
32.5 \\
\\
13.3 \\
8.7 \\
7.6\end{array}$ & $\begin{array}{c}231.0 \\
32.7 \\
\\
14.9 \\
9.3 \\
2.7\end{array}$ & $\begin{array}{c}289.9 \\
39.2 \\
\\
13.2 \\
9.1 \\
6.8\end{array}$ & $\begin{array}{c}208.1 \\
10.7 \\
\\
3.8 \\
6.0 \\
0.7\end{array}$ & $\begin{array}{c}238.7 \\
20.2 \\
\\
4.9 \\
9.2 \\
2.2\end{array}$ \\
\hline $\begin{array}{l}\text { International debt securities (net) issued } \\
\text { by: } \\
\text { Developed countries } \\
\text { Developing countries } \\
\text { Of which: } \\
\text { Asia } \\
\text { Latin America } \\
\text { Eastern Europe }\end{array}$ & $\begin{array}{c}124.0 \\
30.7 \\
\\
11.5 \\
13.6 \\
4.2\end{array}$ & $\begin{array}{c}138.2 \\
33.5 \\
\\
11.0 \\
17.9 \\
2.6\end{array}$ & $\begin{array}{c}83.2 \\
5.2 \\
\\
3.4 \\
-0.7 \\
2.0\end{array}$ & $\begin{array}{c}147.3 \\
9.0 \\
\\
-1.9 \\
8.8 \\
1.7\end{array}$ & $\begin{array}{c}165.7 \\
28.2 \\
\\
5.5 \\
14.2 \\
6.7\end{array}$ \\
\hline
\end{tabular}

The international interbank market might be thought of as having a "precarious credit equilibrium", where at some point lenders may feel they hold potentially legally unenforceable claims, mistrust the quality of public information on the borrower and question the credibility of any government guarantees. ${ }^{68}$ Lending banks are aware that as the capital position of poorly supervised borrowing banks weakens there may be strong incentives for them to take on additional risk and to conceal information regarding their behaviour and performance.

This stylised characterisation of the international banking market as one having severe asymmetric information problems combined with implicit government guarantees for large institutions is obviously an oversimplification. But there is an element of truth in the story. ${ }^{69}$ The credibility of the

68 Niehans (1985) questions the assumption of legal enforceability of claims in international credit markets.

69 The story in many ways is not new. Diaz-Alejandro (1985) emphasised the role of implicit guarantees and poor banking supervision in the Chilean financial crises of the early 1980s. Dooley (1997) develops a similar theme, relating private capital flows to the government's implicit or explicit insurance of intermediaries. 


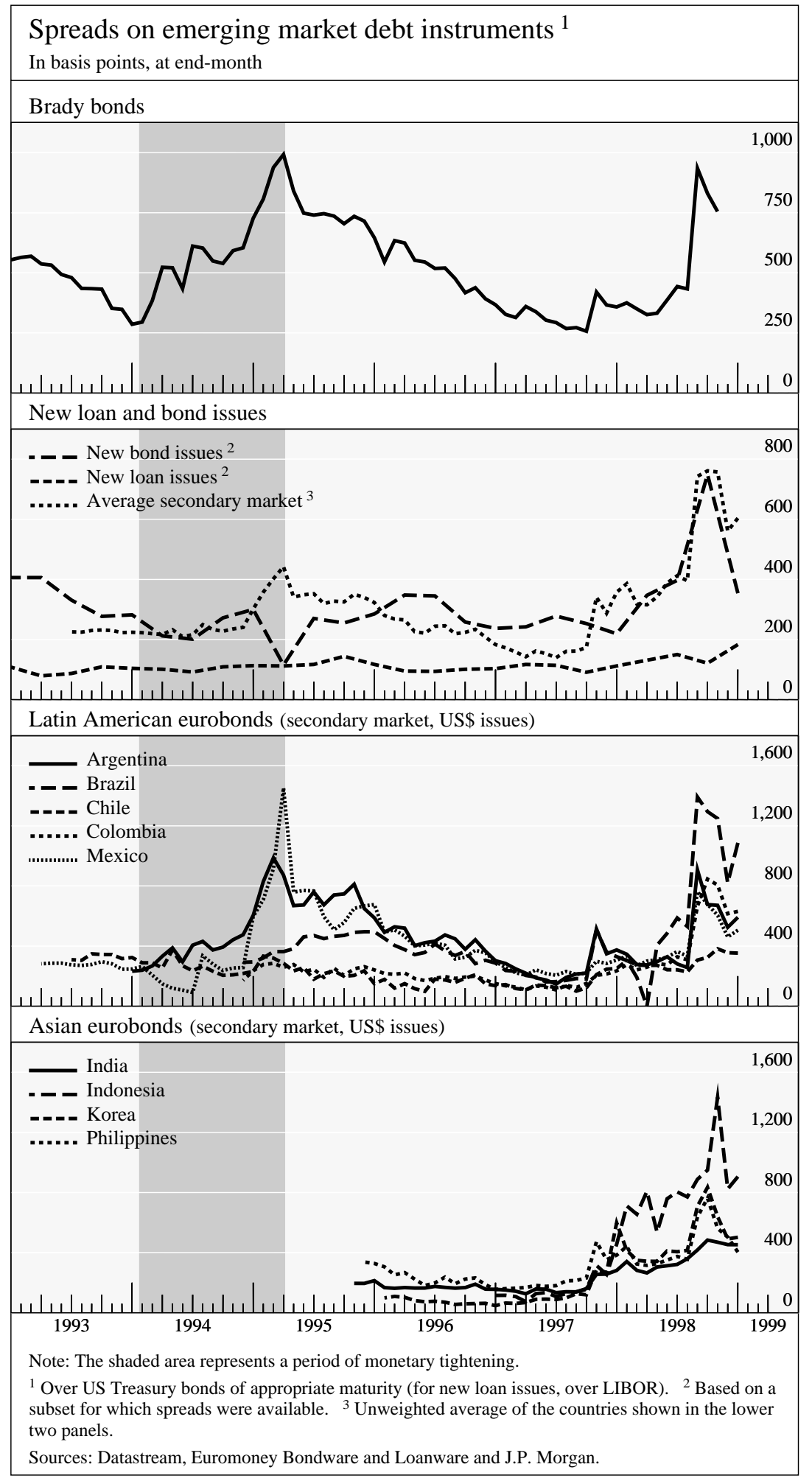


implicit commitment to assist a banking sector in difficulty depends on how large the problem is perceived to be and the ability of the government and the central bank to provide assistance. The limit of this assistance is easily recognised: neither the government nor the central bank can manufacture foreign exchange. Doubtful transparency of the government or private institutions can magnify the concern that problems of illiquidity may turn into questions of solvency.

Guttentag and Herring (1985) earlier raised the issue of implicit official guarantees when considering how the international interbank market avoided disruption from several major shocks which occurred between the 1974 Herstatt crisis and the run on Continental Illinois several years later. Their "suspicion" was that the stability was less the result of the quality of credit evaluation and monitoring of banks in the interbank market and more the implicit guarantees provided by official institutions. ${ }^{70}$

Foreign lenders no doubt are aware of the conflicting incentives of the government, banks and their regulators in the borrower countries and the potential for misrepresentation of the depth of a bank loan problem. The difficulty of verifying the quality of information on borrowers may significantly increase perceptions of credit risks, leading in extreme cases to the equivalent of a bank run. Hence, we might observe a sudden sharp adjustment in lender risk preferences, from modest risk aversion to a widespread flight from risk and a search for safe assets.

The above argument suggests that the international banking market might be interpreted as having "multiple equilibria", where a small departure from the assumption of a credible commitment by the government to the support of the banking system moves the system to one of severe credit rationing. In some instances it may even be the case, as in a domestic bank run, that a change in beliefs unrelated to economic fundamentals, so-called "self-fulfilling prophecies" as in Farmer (1993), leads for some institutions to a cut-off from foreign financing and a liquidity crisis.

What is surprising in retrospect is the size and speed of the increase in foreign claims on private institutions in East Asia, in many cases despite limited transparency regarding the financial status of borrowers. Even when there were signs of potential vulnerability we still observed large short-term capital inflows into several East Asian countries. Korea again provides an example: international interbank claims on Korea continued to grow rapidly between 1994 and 1996 when Korean bank profitability was weakening and bank share prices declining.

70 Federal Reserve Governor Ferguson (1998) has also drawn attention to the role of the implicit safety net in attracting foreign bank creditors to Asia and to the lax standards for transparency and disclosure. Once such moral hazard risk exists it may be difficult to remove. For example, up to 1979 the Argentine central bank fully insured all depositors at its own cost. In November 1979 the central bank dramatically changed the insurance scheme, providing only limited coverage, with institutions not required to join. The new insurance system is said to have altered perceptions of bank risk, but only when the failure of large institutions started to occur. However, Baliño (1991) suggests that some institutions (state banks and branches of foreign banks) which chose not to participate in the new deposit insurance programme were still thought to have de facto insurance. See also Nam (1995). 
The precarious nature of the credit equilibrium in Asian countries was also the result of the conditions in the lending countries over the past few years, as described in the latest Annual Report of the Bank for International Settlements. ${ }^{71}$ The earlier increase in international portfolio investor risk preferences, sometimes described as a greater "appetite for risk", was encouraged by the relatively easy monetary policies in the major industrial economies, reflected in low interest rates and abundant liquidity. This liquidity was directed at the high-growth countries of East Asia, as well as the equity markets in the industrial countries. Spreads on US dollar sovereign international bonds over US Treasury yields fell dramatically for Latin American issuers from 1995 up to mid-1997 and remained very small for Asian borrowers. They have recently dramatically increased.

The picture painted here is one of an earlier abundance of international liquidity and of declining risk aversion of international lenders confronting investment opportunities in high-growth Asian emerging market countries. What may have brought these two together was the assumption, based on the past behaviour of governments, of large implicit credit guarantees for the banking systems of borrowing countries. The impression that these guarantees could not be sustained led to an enormous exodus of foreign short-term capital. We are now observing the second leg of what is here described as a precarious credit equilibrium, a major international investor flight from risk.

\section{Conclusion}

In 1985 Carlos Diaz-Alejandro stated that "the financial history of Latin America remains to be written". Fourteen years later we can reply that it has been but that no one has been reading it. During the early 1980s economists talked of the "Chilean miracle" and of its "remarkable fiscal performance", similar to the euphoria over the "Asian miracle" and Asia's solid macroeconomic fundamentals. In both cases extreme optimism was followed by sudden dismay and financial disarray. The discussion has now changed dramatically, as we attempt to understand why so many were so slow to learn from earlier crises. The financial crisis of East Asia is different from the Chilean crisis of the early 1980s in that an unsustainable exchange rate policy, except in Thailand, was not an obvious trigger for the crisis. Aside from this difference, many of the elements that eventually brought Chile to the brink are similar to those which have seriously weakened Korea, Thailand, Malaysia, Indonesia and the Philippines, all factors which contributed to a "significant microeconomic misallocation of credit".

In searching for an understanding of the origins of the Asian crisis we need to study carefully both the demand and the supply sides of emerging economy financial markets and ask what elements contributed most to the misallocation of credit and the liquidity crisis. This paper has focused on the

71 Bank for International Settlements (1998), Chapter VII. 
contribution of government-guarantee-induced moral hazard problems affecting the behaviour of large borrowers and lenders in recently deregulated financial systems. We have emphasised the immature nature of some of these systems, their bank domination, and their underlying structural vulnerability. The weaknesses in financial transparency, corporate governance, and prudential regulation and supervision in a high-growth environment led to excessive credit creation, asset price booms and large foreign currency exposure. Banking systems intermediating enormous short-term capital inflows took on risks they could not properly manage. As in several previous crises, a serious vulnerability was the loosely regulated behaviour of aggressive non-bank financial intermediaries. We have tried to emphasise that this pattern of behaviour was by no means unique to East Asia, nor were the resulting crises. Countries which have significantly deregulated their financial systems have often been slow to improve market-driven corporate governance and credit screening and monitoring structures which might contribute to their stability. They have also been slow to reinforce the prudential regulation and supervision of banks and new non-bank financial intermediaries.

On the supply side, attention has been drawn to the precarious credit equilibrium in international banking markets, in which there appears to be a surprising lack of desirable credit rationing in the face of major deficiencies in borrower transparency, which during stress periods can lead to severe credit rationing and a liquidity crisis. Foreign lenders may have relied excessively on implicit government guarantees in extending large credits to East Asian borrowers. This too is behaviour we have observed in earlier Latin American crises. Many investors were aware that the financial transparency of individual enterprises and intermediaries was wanting in East Asian countries. Moreover, there was plenty of available evidence pointing to the short-term foreign currency exposure of banks and nonbanks and to the deficiencies of banking supervision and prudential regulation. Few appeared to heed these signs. 


\section{References}

Akerlof, George A and Paul M Romer (1993): "Looting: the economic underworld of bankruptcy for profit”. Brookings Papers on Economic Activity, No. 2.

Akrasanee, Narongchai (1998): "Recent financial and economic crisis in Thailand". Paper prepared for the Conference on Asian Crisis, co-organised by Asia-Europe Foundation and the Centre d'Etudes Prospectives et d'Informations Internationales, 11-12 May, Paris.

Alchian, Armen (1950): "Uncertainty, evolution and economic theory". Journal of Political Economy, June.

Allen, Franklin (1983): “Credit rationing and payment incentives". Review of Economic Studies.

Andersen, Palle Schelde (1993): "Economic growth and financial markets in selected Asian countries", in Finance and the International Economy: 7, The AMEX Bank Review Prize Essays, Richard O’Brien (ed.), Oxford University Press.

Baliño, Tomas J T (1991): "The Argentine banking crisis of 1980", in Banking crises: cases and issues, V Sundararajan and Tomas J Baliño (eds.), International Monetary Fund.

Bank for International Settlements (1998): 68th Annual Report, June.

The Bank of Korea (1995): Financial System in Korea.

The Bank of Korea (1998): "Asset price inflation and monetary policy: the case of Korea". Country paper for the EMEAP's asset pricing study, July.

The Bank of Korea (1998): Financial Crisis in Korea: Why it happened and how it can be overcome. Research Department, July.

Bank of Thailand (1998): Annual Economic Report 1997.

Barnea, Amir, Robert A Haugen and Lemma W Senbet (1985): "Agency Problems and Financial Contracting". Prentice-Hall, Englewood Cliffs, New Jersey.

Bisat, Amer, R Barry Johnston, and V Sundararajan (1992): "Issues in managing and sequencing financial sector reforms: lessons from experiences in five developing countries". IMF Working Paper No. 92/82, International Monetary Fund, Washington, D.C.

Bisignano, Joseph (1998): "Towards an understanding of the changing structure of financial intermediation: an evolutionary theory of institutional survival". SUERF Studies No. 4, Société Universitaire Européenne de Recherches Financières, Amsterdam.

Calomiris, Charles W (1998): "The IMF's imprudent role as lender of last resort". The Cato Journal.

Caprio, Gerard Jr (1997): "Safe and sound banking in developing countries: we're not in Kansas anymore". Policy Research Working Paper No. 1739, The World Bank, March.

Cho, Yoon (1986): "Inefficiencies from financial liberalisation in the absence of well-functioning equity markets". Journal of Money, Credit and Banking.

Dewatripont, M and E Maskin (1995): "Credit and efficiency in centralised and decentralised economies". Review of Economic Studies.

Diaz-Alejandro, Carlos F (1985): "Good-bye financial repression, hello financial crash". Journal of Development Economics, September/October.

Dickie, Paul M (1997): “Toward resilient financial systems", in Creating Resilient Financial Regimes in Asia: Challenges and Policy Options. Proceedings of an Asian Development Bank Seminar, Manila, 29 April 1996, Priya Basu (ed.), Oxford University Press, Hong Kong. 
Dooley, Michael P (1997): “A model of crises in emerging markets”. NBER Working Paper No. 6300, December.

Drees, B and C Pazarbasioglu (1998): "The Nordic banking crisis: pitfalls in financial liberalisation?" Occasional Paper No. 161, International Monetary Fund, Washington, D.C.

Edwards, Sebastian and Alejandra Cox Edwards (1987): Monetarism and Liberalisation: The Chilean Experiment. The University of Chicago Press, Chicago.

Edwards, Sebastian (1995): "Public sector deficits and macroeconomic stability in developing countries", in Budget Deficits and Debt: Issues and Options. A Symposium Sponsored by the Federal Reserve Bank of Kansas City, Jackson Hole, Wyoming, 31 August - 3 September.

Englund, Peter (1990): "Financial deregulation in Sweden". European Economic Review.

Farmer, Roger E A (1993): “The macroeconomics of self-fulfilling prophecies". The MIT Press, Cambridge, Massachusetts.

Ferguson, Roger W Jr (1998): “Themes in international bank supervision". Speech delivered to the Federal Financial Institutions Examination Council, International Banking Council, Arlington, Virginia, 20 July.

Folkerts-Landau, David, Garry J Schinasi, Marcel Cassard, Victor K Ng, Carmen M Reinhart and Michael G Spencer (1995): "Effects of capital flows on the domestic financial sectors in APEC developing countries", in Moshin Khan and Carmen Rheinhart (eds.), Capital Flows in the APEC Region. IMF Occasional Paper No. 122. International Monetary Fund, Washington, D.C.

Fukao, Mitsuhiro (1998): "Japanese financial instability and weaknesses in the corporate governance structure". Discussion Paper No. 9801, Faculty of Business and Commerce, Keio University, Tokyo, May.

Garcia-Herrero, Alicia (1997): "Banking crises in Latin-America in the 1990s: Lessons from Argentina, Paraguay, and Venezuela". Working Paper 97/140, International Monetary Fund, October.

Goldsmith, Raymond (1982): "Comment" in Financial Crises: Theory, History and Policy. Charles P Kindleberger and Jean-Pierre Laffargue (eds.), Cambridge University Press.

Goldstein, Morris and Philip Turner (1996): "Banking crises in emerging economies: origins and policy options". BIS Economic Papers No. 46, October.

Gramlich, Edward (1998): "World capital flows: let's fix the system, not abandon it". Remarks at the Carnegie Bosch Institute, University Centre of at Carnegie Mellon, Pittsburgh, 15 September.

Greenspan, Alan (1998): "Remarks at the 34th Annual Conference on Bank Structure and Competition". Federal Reserve Bank of Chicago, 7 May.

Guttentag, Jack and Richard Herring (1985): "Funding risk in the international interbank market", in International Financial Markets and Capital Movements: A Symposium in Honor of Arthur I Bloomfield, W J Ethier and R C Marston (eds.). Essays in International Finance, No. 157, Princeton University, September.

Harberger, Arnold C (1985a): “Observations on the Chilean Economy, 1973-1983”. Economic Development and Cultural Change, April.

Harberger, Arnold C (1985b): "Lessons for debtor country managers and policymakers", in International Debt and the Developing Countries, Gordon W Smith and John T Cuddington (eds.), The World Bank, Washington, D.C.

Huh, Chon and Sun Bae Kim (1994): "Financial regulation and banking sector performance: a comparison of bad loan problems in Japan and Korea". Economic Review, Federal Reserve Bank of San Francisco, No. 2. 
Ingves, Stefan (1997): "Experiences from the Swedish bank crisis 1991 to 1994: with a view to strengthening future financial stability". Paper presented at the conference Managing Systemic Risk, London, 3-4 December.

International Monetary Fund (1997): World Economic Outlook: Interim Assessment, December.

Ito, Takatoshi (1996): "Japan and the Asian economies: a "miracle" in transition". Brookings Papers in Economic Activity, No. 2.

Jaffee, D and T Russell (1976): “Imperfect information, uncertainty and credit rationing”. Quarterly Journal of Economics.

Jonung, Lars (1986): "Financial deregulation in Sweden". Skandinaviska Enskilda Banken Quarterly Review.

Kane, Edward J (1991): "Financial regulation and market forces". Schweizerische Zeitschrift für Volkswirtschaft und Statistik, September.

Kane, Edward J (1998): "Offshore financial regulation competition: a force for modernisation and for crisis". Paper prepared for the Conference on Financial Modernisation and Regulation, Federal Reserve Bank of San Francisco, September.

Kim, In-June and Yeongseop Rhee (1998): "Currency crisis of the Asian countries in a globalised financial market". Paper presented at the Bank of Korea conference on "The implications of globalisation of world financial markets", 22-23 June.

Kiyotaki, Nobuhiro and John Moore (1997): "Credit cycles". Journal of Political Economy, April.

Krugman, Paul (1991): "Financial crises in the international economy" in The Risk of Economic Crisis, Martin Feldstein (ed.), The University of Chicago Press.

Krugman, Paul (1994): “The myth of Asia's miracle”. Foreign Affairs, November/December.

Krugman, Paul (1998a): "What happened to Asia?". PK Home Page, January.

Krugman, Paul (1998b): “Saving Asia: it’s time to get radical”. Fortune, 7 September.

Layman, Thomas A (1988): "Monetary policy and financial reform in Korea" in Monetary Policy in Pacific Basin Countries. Papers Presented at a Conference Sponsored by the Federal Reserve Bank of San Francisco, Hang-Sheng Cheng (ed.), Kluwer Academic Publishers, Boston.

Le-Fort, Guillermo (1994); "The financial system and macroeconomic stability: the Chilean experience", in Financial Sector Reforms, Economic Growth, and Stability: Experiences in Selected Asian and Latin American Countries, Shakil Faruqi (ed.), EDI Seminar Series, The World Bank, Washington D.C.

Lee, In Ho (1998): "Korean financial crisis: a price for a miracle". Paper presented at the CEPR/ESRC/GEI Conference, World Capital Markets and Financial Crises, University of Warwick, 24-25 July.

Lindgren, Hakan (1990): "Long-term contracts in financial markets: bank-industry connections in Sweden, illustrated by the operations of Stockholms Enskilda Bank, 1900-70" in The firm as a nexus of treaties, Masahiko Aoki, Bo Gustafsson and Oliver E Williamson (eds.), Sage Publications.

Lowe, Philip (1992): "The impact of financial intermediaries on resource allocation and economic growth". Research Discussion Paper No. 9213, Reserve Bank of Australia, December.

McKinnon, Ronald I (1982): "The order of economic liberalisation: lessons from Chile and Argentina". Carnegie-Rochester Conference Series on Public Policy, Volume 17, Autumn.

McKinnon, Ronald I (1991): The order of economic liberalisation: financial control in the transition to a market economy. The Johns Hopkins University Press, Baltimore. 
McKinnon, Ronald I and Huw Pill (1996): "Credible liberalization and international capital flows: the 'overborrowing syndrome"', in Financial Deregulation and Integration in East Asia, Takatoshi Ito and Anne O Krueger (eds.), The University of Chicago Press.

McKinnon, Ronald I and Huw Pill (1998): "The overborrowing syndrome: are East Asia countries different?" in Managing Capital Flows and Exchange Rates: Perspectives from the Pacific Basin, Reuven Glick (ed.), Cambridge University Press.

Miller, Merton H (1998): "The current Southeast Asia financial crisis". Pacific-Basin Finance Journal, August.

Nam, Sang-Woo (1995): "Korea's financial markets and policies", in Financial sector development in Asia, Shahid N Zahid (ed.), Asian Development Bank.

Nasution, Anwar (1985): "Financial sector development in Indonesia" in Financial sector development in Asia, Shahid N Zahid (ed.), Asian Development Bank.

Niehans, Jurg (1985): "International debt with unenforceable claims". Federal Reserve Bank of San Francisco Review, Winter.

O’Connell, S A and S P Zeldes (1988): "Rational Ponzi games". International Economic Review.

Park, Jong-Suk (1998): "The nature and role of deposit insurance in Korea". Paper presented at the International Conference on Deposit Insurance, Federal Deposit Insurance Corporation, 8-11 September.

Park, Won-Am (1996): "Financial liberalisation: the Korean experience", in Financial Deregulation and Integration in East Asia, Takatoshi Ito and Anne O Krueger (eds.), The University of Chicago Press.

Park, Yung Chul (1991): "Financial repression and liberalisation" in Liberalisation in the Process of Economic Development, Lawrence B Krause and Kim Kihwan (eds.), University of California Press, Berkeley.

Park, Yung Chul (1996): "East Asian liberalisation, bubbles, and the challenge from China". Brookings Papers on Economic Activity, No. 2.

Park, Yung Chul (1998): "What have we learned from the Korean financial crisis?". Korean Institute of Finance. Paper prepared for the CEPII conference on the Asian Crisis, Paris, 11-12 May.

Piei, Mohd Haflah and Mohamed Ariff (1998): "Crisis and lessons of the Asian Crisis: Malaysian Perspective". Malaysian Institute of Economic Research, May.

Radelet, Steven and Jeffrey D Sachs (1998): "The East Asia financial crisis: diagnosis, remedies, prospects". Brookings Papers on Economic Activity, No. 1.

Radelet, Steven and Jeffrey D Sachs (1998): "The onset of the East Asia financial crisis". Harvard Institute for International Development, mimeo, 30 March.

Randall, Richard A (1989): "Can the market evaluate asset quality exposure in banks?" New England Economic Review, Federal Reserve Bank of Boston, July/August.

Rojas-Suárez, Liliana and Steven R Weisbrod (1995): "Financial fragilities in Latin America: the 1980s and the 1990s". Occasional Paper No. 132, International Monetary Fund, Washington, D.C.

Shapiro, Harvey D (1997): "How high is up?" Institutional Investor, March.

Standard \& Poor's (1998a): "Sovereign credit analysis: new environment after Asian crisis". Standard and \& Poor's Credit Week, 18 February.

Standard \& Poor's (1998b): “Global financial system stress: leading indicators signal pressure in 16 countries". Standard and \& Poor's Credit Week, 16 September.

Stiglitz, Joseph E and Andrew Weiss (1981): "Credit rationing in markets with imperfect information". The American Economic Review, June. 
Stiglitz, Joseph E (1991): "Governments, financial markets, and economic development". NBER Working Paper No. 3669, April.

Stiglitz, Joseph E and Marilou Uy (1996): "Financial markets, public policy, and the East Asian Miracle". The World Bank Research Observer, August.

Sundararajan, V and Tomas J T Baliño (1991): "Issues in recent banking crises", in Banking Crises: Cases and Issues, V Sundararajan and Tomas J T Baliño (eds.), International Monetary Fund, Washington, D.C.

Suzuki, Yoshio (1986): "Money, Finance, and Macroeconomic Performance in Japan". Yale University Press, New Haven.

Velasco, Andrés (1987): "Financial crises and balance of payments crises: a simple model of the Southern Cone experience", in International Trade, Investment, Macro Policies and History: Essays Memory of Carlos F Diaz-Alejandro. P Bardhan, A Fishlow and J Berhman (eds.), North-Holland, Amsterdam.

Velasco, Andrés (1991): "Liberalisation, crisis, intervention: the Chilean financial system, 1975-85", in Banking Crises: Cases and Issues, V Sundararajan and Tomas J T Baliño (eds.), International Monetary Fund.

Weinstein, David E and Yishay Yafeh (1998): "On the costs of a bank-centred financial system: evidence from the changing main bank relations in Japan". The Journal of Finance, April.

World Bank (1993): “The East Asian Miracle: Economic Growth and Public Policy". World Bank Policy Research Report, Oxford University Press.

World Bank (1998): "Global Development Finance: Analysis and Summary Tables". Washington, D.C. 




\section{Recent BIS Working Papers}

No.

48

September 1997

49

September 1997

50

November 1997

51

November 1997

52

January 1998

53

March 1998

54

June 1998

55

June 1998

56

June 1998

57

July 1998

58

November 1998

59

November 1998

60

November 1998

61

November 1998

62

March 1999

63

March 1999
Title

Some multi-country evidence on the effects of real exchange rates on output

Why does the yield curve predict economic activity?

Dissecting the evidence for Germany and the United States

The euro and the dollar

Forecast errors and financial developments

Inflation and disinflation in Iceland

Exchange rate regimes and inflation and output in

Sub-Saharan countries

The coming transformation of continental European banking?

Spread overreaction in international bond markets

Commercial banks in the securities business: a review

One-step prediction of financial time-series

The importance of bank seniority for relationship lending

Portfolio selection using fuzzy decision theory

Output gap uncertainty: does it matter for the Taylor rule?

Foreign direct investment and employment in the industrial countries

The pricing of bank lending and borrowing: evidence from the federal funds market

Microeconomic inventory adjustment and aggregate dynamics
Author

Steven B Kamin and Marc Klau

Frank Smets and

Kostas Tsatsaronis

Robert N McCauley

Palle S Andersen

Palle S Andersen and Már Guðmundsson

Marc Klau

William R White

Gregory D Sutton

João A C Santos

Srichander

Ramaswamy

Stanley D Longhofer and João A C Santos

Srichander

Ramaswamy

Frank Smets

P S Andersen and P Hainaut

Craig H Furfine

Jonathan McCarthy and Egon Zakrajšek 